\title{
Role of Trade and Macroeconomic Policies in the Performance of Special Economic Zones (SEZs)
}

\author{
Sebastian Morris
}

W.P. No.2007-09-02

September 2007

The main objective of the working paper series of the IIMA is to help faculty members, research staff and doctoral students to speedily share their research findings with professional colleagues and test their research findings at the pre-publication stage. IIMA is committed to maintain academic freedom. The opinion(s), view(s) and conclusion(s) expressed in the working paper are those of the authors and not that of IIMA.

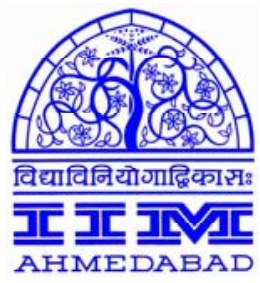

INDIAN INSTITUTE OF MANAGEMENT

AHMEDABAD-380 015

INDIA 


\title{
Role of Trade and Macroeconomic Policies in the Performance of Special Economic Zones (SEZs) ${ }^{1}$
}

\author{
Sebastian Morris ${ }^{2}$
}

\begin{abstract}
Special economic zones following the enormous success of China have been widely imitated. But it is to be entirely anticipated that the results would vary greatly. Earlier avatars of SEZs in the form of Foreign Trade Zones (FTZs) and Export Promotion Zones (EPZs) were important in the export led growth of east Asia especially South Korea. But more than SEZs or EPZs per se it is the pursuit of "export led growth policies" which underlie the success of exporting and hence of SEZs. SEZz / EPZs can be seen as a (not necessary) microeconomic and spatial initiative in the pursuit of ELG under rather special circumstances by China, and South Korea and Taiwan to more limited extent in their early phases of transformation. In other countries not pursuing ELG the success of SEZs/EPZs has been rather modest. The roles played by the SEZs/EPZs etc whatever their original purpose were constrained and determined by the macroeconomic policies, trade policies, and regional alignments. There is little meaning in studying SEZs beyond their layout and design without reference to these broader trade and macroeconomic policies. Thus early pioneers line India could make little out of their EPZs since the policies severely biased against exports. We characterise export led growth (ELG) as the strategy that has allowed the late twentieth century industrialisations, which is far from both import substitution (as conventionally understood) and laissez faire, and to be the simultaneous pursuit of both IS and EP. With this framework we are able to understand the role and evolution of SEZs in a wide variety of countries. These help us to explain and anticipate that unless the policy turns sharply to favours exports (more correctly tradables over non tradables) the success of Indian SEZs would be modest and nowhere near that registered in China. Following from our characterisation of Import Substitution, Export Led Growth and Laissez Faire we also bring out the nature and performance of "special zones" when these are promoted under the very same regimes.
\end{abstract}

\footnotetext{
${ }^{1}$ Based on the report of a study sponsored by the UK High Commission in India. The author is grateful for the support provided. The author particularly thanks Mss. Dharti Daftary, Stuti Jha and Nicola Murray of the UK High Commission for their support and confidence. This paper is one of the three papers on SEZs in India. All views here are those of the author and not of either the UK High Commission or the Indian Institute of Management Ahmedabad. The term SEZ is used to cover all particular area or zone based development especially of exports and includes export promotion zones (EPZs), Free trade zones (FTZs) and such other zones.

${ }^{2}$ Professor, Indian Institute of Management Ahmedabad 380015, INDIA. Email: morris@iimahd.ernet.in
} 


\section{Role of Trade and Macroeconomic Policies in the Performance of Special Economic Zones (SEZs)}

\section{Introduction}

Following especially the remarkable success of China in the use of SEZs to promote exports and attract apparently vast amounts of FDI, there is much hope that other countries could do as much. Since SEZs are more visible and concrete evidences of the actions of the Chinese state to foster the rapid and sustained transformation of the economy, they more than the intangibles - the nuances and details of the policies and measures that constitute export orientation - have been imitated widely. Results though have been high variable. We claim that the core reason for the success of China and East Asia lie in the macroeconomic policies and strategies for -viz its pursuit of export led growth (ELG) that these countries adopted. Indeed ELG with or without zones would be just as effective for countries like India. Unfortunately the false notion that ELG is nothing other than laissez faire has held back the correct macro economic policies from being pursued. The characterisation of ELG is carried out in Section 1 and aspects of ELG in relation to both import substitution (IS) and laissez faire (LF) brought out in table 1. This section although not part of the discussion on SEZs, is important since it lays out the correct characterisation of ELG as essentially different from both laissez faire and import substitution (IS). Since this understanding has not yet found recognition in the literature we bring out the same in some detail based on our earlier work.

This is followed by a consideration of SEZs in a variety of countries relating the experience to the overall development strategies that these countries followed. This is carried out in Section 2. In Section 3 the Chinese case is brought out with some of the more significant contrasts with the India. In Section 4 the phases in Chinese SEZs along with some reference to its transformation is discussed. In Section 5 very briefly the experiences of Philippines, Russia and Sri Lanka are brought out. In Section 6 (table 4) the influences on SEZs arising out of the strategy of economic transformation and growth pursued are brought out. The issues arising out the size, location, infrastructure, access to central places, fiscal incentives, in the design of SEZs are related directly to the policies for SEZs. These are covered in Pandey, Ajay (2006). 


\section{SECTION 1 : EXPORT LED GROWTH, IMPORT SUBSITUTION AND LAISSEZ FAIRE}

The remarkable success of East Asian transformations (South Korea, Taiwan, HK, Singapore and now China, Thailand, Vietnam and Malaysia) has attracted the attention of governments, development scholars, policy makers, politicians and global developmental agencies. It is well accepted that the stupendous rise in the manufactured exports from these countries underlay their success, although the exact content of the policy or policies that may be called "Export led growth", is even now incorrectly understood. Governments have attempted to imitate the East Asian countries and in this attempt the more visible parts of the strategy - export subsidies and the setting up special especially of export zones - have naturally had many followers. But outside the region success has been elusive and there is no single country in either Latin America or Africa that can show the same success. The case of Latin American countries which despite all the endowments necessary for growing all the way to being advanced capitalist countries is the most remarkable contrast. ${ }^{3}$ The recognition that barring the East Asian there have been no really independent transformations ${ }^{4}$ in the second half of the $20^{\text {th }}$ century would give added weight to the importance of the East Asian industrialisation and to its correct understanding. In reality much of the success arose out of the pursuit of policies that would either be considered as impossible by many economists or would be in contradiction with their prescriptions. (See discussion in Section 1).

The contrast is especially stark with regard to the usual prescriptions of the multilateral organisations especially the IMF and the WB, through the latter has been quick to appropriate the success of East Asia to a vindication of its prescriptions for laissez faire trade. (Cf. Little, I.M. D., 1981; Page, 1994; World Bank, 1993). But East Asian approach while in many ways have varied the underlying core of the strategy, despite this variety can be effectively characterised. The strategy has to be understood as a whole and references to particular elements in isolation has lead to either disbelief or to incorrect understanding. (Alam,1989; S. Morris, S., 1997, 2005)

\footnotetext{
${ }^{3}$ The continuation of the Latin American countries as middle income over much of the twentieth century needs explanation. None of the mainstream stories are really explanations. High inflation leading capital flight is often blamed as if inflation is an exogenous aspect. The only possible explanation is that these countries in having open capital accounts and the class basis for capital flight they lose much of their investible resources. Thus years of growth are typically followed by years of decline with the global capital movements amplifying the cycles and on a net basis leading capital flight. The fact that the elite among these societies have their interest in Europe and America implies that policies are geared to allow the accumulation of financial savings and their spending in the metropole countries, to support which vast capital flight becomes necessary. Capital flight is made possible by interalia by exchange rates that are maintained during periods of flight, followed by large depreciation/ devaluations, to leave post exit high inflation as the only way of adjustment. The structural underpinnings of Latin America's delayed industrial growth from the very beginning of the rise of capitalism and under import substitution (See for instance Frank, A. G. (1975); Pastor-Jr, M. (1990) and Furtado, Celso (1963); Petras, J. and H. Brill (1988); Baer, W. and K. Hargis (1997).) and the de-nationalisation of many of their economies have been brought out by the underdevelopment school and its variants. (Evans, Peter B. (1979); Altman, E. I. and I. Walter (1980). Thus, during much of industrial growth in Brazil in the post World War II period, policies were severely biased against exports. Cf. Tyler, et al. (1985).

${ }^{4}$ The transformations of countries such a Portugal and Ireland are on the back of their membership/ easy access to the markets of already transformed Western Europe.
} 
In another paper (Morris, S., 1997) we have explained ELG as the simultaneous pursuit of export promotion and import substitution which to most economists brought upon the standard 2X2X2 model of trade, would seem like impossibility. We have shown that with the introduction of a non-traded sector it is conceptually possible for both export promotion and import substitution to take place. We also argue that the observation that the ratio of $\boldsymbol{P}_{\boldsymbol{m}} / \boldsymbol{P}_{\boldsymbol{x}}$ (Price of exportables to importables) being close to the border ratio does not mean that these (ELG) economies were following laissez faire as John Page (1994) of the World Bank presumes it to be. It actually means that that in these countries the ratio of $\boldsymbol{P}_{\boldsymbol{X}} / \boldsymbol{P}_{\boldsymbol{n} \boldsymbol{t}}$ and $\boldsymbol{P}_{\boldsymbol{m}} / \boldsymbol{P}_{\boldsymbol{n} \boldsymbol{t}}\left(\boldsymbol{P}_{\boldsymbol{n} \boldsymbol{t}}\right.$-Price of non-tradables) were both much larger than in other countries so that there were strong incentives to produce both import goods and to export. In doing so the increased production of tradables was demand pulled so that idle/ underutilised labour resources could be fully utilised. .

Only this could have ensured a 350 times increase in manufactured exports from Korea over a 15 year period (1965 to 1980) and about the same increase from China in recent times. Thus the gains from trade in ELG (unlike in laissez faire) does not come from specialisation per se across countries (which are usually estimated to be of the order of a few percent at most in many empirical studies) but from the use of idle / underutilised labour in the late industrialising country pursuing ELG. The understanding of the structuralists that South Korea and Taiwan, the earliest of the ELG countries had significant state intervention demolished the non-intervention thesis of many like Little, I.M.D (1981). But that understanding was inadequate to explain why despite the intervention (widely admitted and obvious to even casual scholars) ELG countries even South Korea and Taiwan showed $\boldsymbol{P}_{\boldsymbol{m}} / \boldsymbol{P}_{\boldsymbol{x}}$ ratios closer to the border prices unlike in the case of import substitution economies (most LDCs including India) which showed $\boldsymbol{P}_{\boldsymbol{m}} / \boldsymbol{P}_{\boldsymbol{x}}$ to be much greater than the border prices. The explanation of the strategy developed in Morris, S., (1997) and the macroeconomic dimensions of the same in the case of China elaborated in Morris, S. (2005) together is the only understanding that can square up with the observed facts across the set of ELG countries. One key aspect of ELG is the policy induced structural undervaluation of the effective exchange rate. Thus we observe that the ratio of exchange rate GDP / Purchasing Power GDP from 1 after removing its systematic dependence on country size and level of development of the economy has in a relative sense (relative to all countries) been much less than zero for all ELG countries for which reliable data was available (original PPP data from Mark5 World Penn Tables, International Comparison Project). For both China and India before 1978 it was greater than zero indicating the large overvaluation under traditional import substitution. For China after the "open door policy" c.1979 the value goes far below zero and stays at that level while the exports grow at rates that exceeded 22\% per annum in dollar terms on a sustained basis. For India the value since the 80 s has been closer to zero implying the movement to equilibrium pricing rather to promotion of tradable goods through policy induced undervaluation. See Fig. $1^{5}$.

\footnotetext{
${ }^{5}$ Since this is not a paper in either growth strategies or macroeconomics, the reader is referred to Morris, S. (1997) and to Morris, S. (2005) for discussion of the characterization of ELG as in here and for the use of the same framework to understand the case of Indian growth since 1992, and the Chinese over the period since the "open-door policies".
} 


\section{SECTION 2: \\ SEZs AND GROWTH STRATEGIES}

See tables 2 and 3 which outline the employment in SEZs as put together by the ILO. As can be seen the use of SEZs by China and other Asian countries is overwhelming large and successful SEZs are a phenomenon of exporting Asia and to a lesser extent Latin America. But with over 7500 zones they have been widely imitated.

\begin{tabular}{|l|r|r|r|r|r|}
\hline \multicolumn{7}{|c|}{ Table 2. Estimates of the Development of Export Processing Zones } \\
\hline & $\mathbf{1 9 7 5}$ & $\mathbf{1 9 8 6}$ & $\mathbf{1 9 9 5}$ & $\mathbf{1 9 9 7}$ & $\mathbf{2 0 0 2}$ \\
\hline No. of countries with EPZs & 25 & 47 & 73 & 93 & 116 \\
\hline No. of EPZs & 79 & 176 & 500 & 845 & 3 \\
& & & & & 000 \\
\hline Employment (millions) & n.a & n.a & n.a & 22.5 & 43 \\
\hline - of which China & 0.8 & 1.9 & n.a. & 4.5 & 13 \\
\hline - other countries for which figures available & & & & & \\
\hline $\begin{array}{l}\text { Total countries for which data were available } \\
\text { (108) }\end{array}$ & & & & & \\
\hline $\begin{array}{l}\text { Source: ILO calculations based on a variety of sources including zone administrations, national } \\
\text { statistics, web sites, published articles, estimates and responses to ILO surveys, updated to Dec. } \\
\text { 2002; from International Labour Office Gb.286/Esp/3, 286th Session, Governing Body Geneva, } \\
\text { March 2003, Committee On Employment And Social Policy Esp, Third Item On The Agenda, } \\
\text { Employment And Social Policy In Respect Of Export Processing Zones (EPZs) } \\
\text { (http://www.ilo.org/public/english/dialogue/sector/themes/epz/stats.htm) }\end{array}$ \\
\hline
\end{tabular}

\begin{tabular}{|l|r|r|}
\hline \multicolumn{1}{|c|}{ Table 3: Employment in Export Processing Zones Across Regions } \\
\hline Geographical Area & Employment & $\begin{array}{r}\text { Number of } \\
\text { zones }\end{array}$ \\
\hline Asia & $36,824,231$ & 749 \\
\hline - of which China & $(2,000,000)$ & \\
\hline $\begin{array}{l}\text { - of which BGMEA factories in } \\
\text { Bangladesh }\end{array}$ & $2,241,821$ & 3300 \\
\hline Central America \& Mexico & 691,397 & 37 \\
\hline Middle East & 440,515 & 23 \\
\hline North Africa & 431,348 & 64 \\
\hline Sub-Saharan Africa & 330,000 & 713 \\
\hline North America & 311,143 & 39 \\
\hline South America & 245,619 & 90 \\
\hline Transition Economies & 226,130 & 87 \\
\hline Caribbean & 127,509 & 3 \\
\hline Indian Ocean & 50,830 & 55 \\
\hline Europe & 13,590 & 14 \\
\hline Pacific & $41,934,133$ & 5,174 \\
\hline Total & \multicolumn{2}{|}{} \\
\hline $\begin{array}{l}\text { Source: ILO, International Labour Office. } \\
\text { (http://www.ilo.org/public/english/dialogue/sector/themes/epz/stats.htm) }\end{array}$ & \\
\hline
\end{tabular}


Fig.1 : Deviations of Exchange Rate GDP/PPP GDP from Structurally Determined Values (Source: Morris, S.

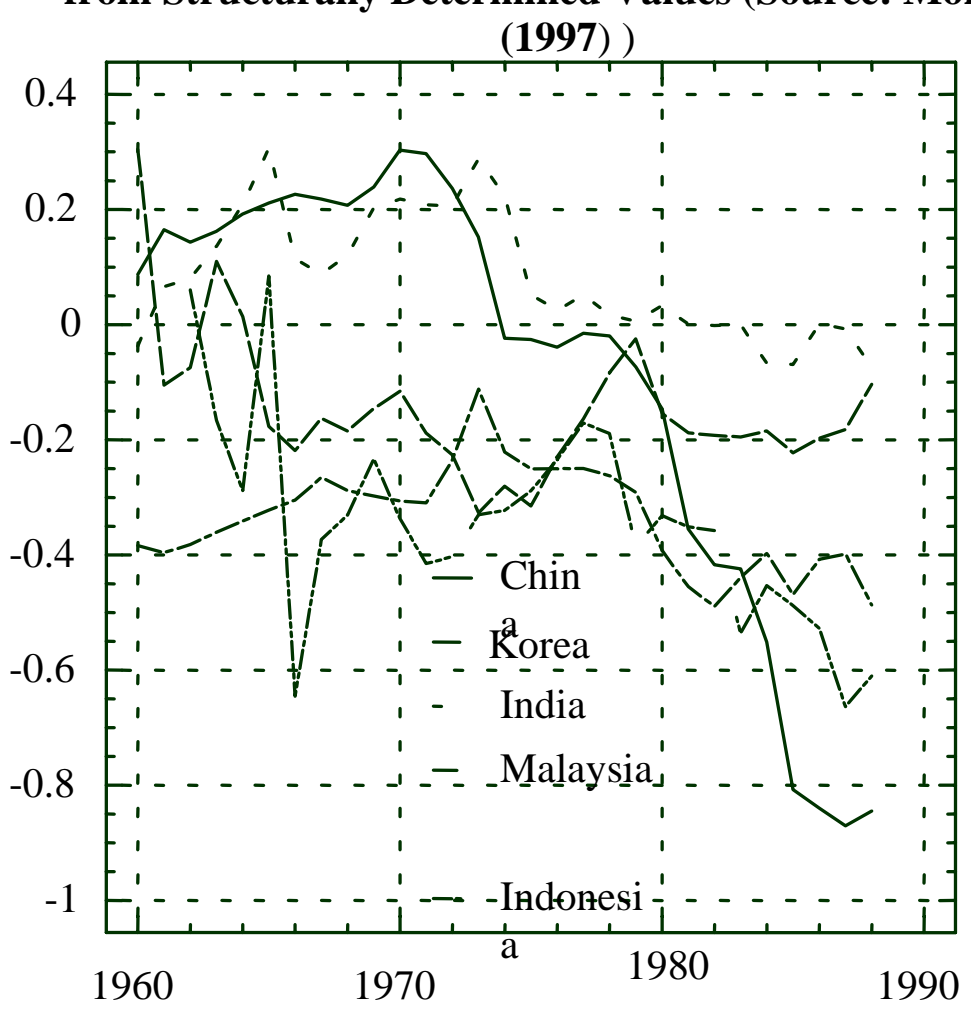

Year

Special economic zones have been widely imitated from Latin America to Africa but export led growth has not followed. Today in India policy after having promoted "Free" trade zones, export promotion zones, now attempts to promote special economic zones. The fond hope in this effort is that the Indian economy especially its manufacturing sector which has been under assault of imports from China would be able to withstand the same and perhaps even be able to follow China in exporting to the world. In most of the countries that attempted to imitate the East Asian countries their special economic zones have played roles quite different from those in East Asia and these roles have been determined by the overall macroeconomic policies, state strategy besides geo-politics. The internal design, layout and management of SEZs whatever be the initial plans may have tended to veer towards serving the specific role that the SEZ ended up performing, within the constraints of overall macroeconomic policies and the strategy of development pursued.

\section{FTZs under Bias against Exports}

Thus in the Indian case the earlier free trade zones (FTZs) and export promotion zones (EPZs) ended up being more custom bond houses with some assembly and manufacturing. Growth remained small and the pressures to expand the size of the zones were never large. Nor did the expected spillover effects of manufacturing within the zone on outside manufacturing materialise. The incentive to set up activity in these zones were constrained by the severe basis against exports right until 1993, the anti-export bias of much of Indian policy until 1993. The poor-economic and political relations with the larger of the country's neighbours kept the role of the zones marginal even in border trade 
. Thus there are no zones that cater to trade with its neighbours despite the enormous potential if one were to go by the experience of Thailand with its neighbours (Maneepong, C., 2004) or China and its land neighbours. The units that came up in these centres did so more out of the need to overcome costs (taxes, and custom duties) on such operations as assembly and manufacture of electronic parts in India. Thus for example until almost 1993, the policy attempted to protect all segments of the electronic industry including such scale and R\&D intensive industries like DRAMs and chip manufacturing. And in the process the policy hurt many industries in electronics typically assembly, the cladding of chips, manufacture of PCBs, design of computers and ICs, software, back office operations, cross border data related industries, etc which were skill labour intensive. All of these had enormous export potential.

Few outside the country are appreciative of the deep biases against exports of Indian post independence polices which continued till as late as 1993 and even now cannot be supposed to have been entirely overcome ${ }^{6}$. In the Mumbai zone (Santa Cruz Export Promotion Zone) the freedom of being allowed to import computers and the access to white collar workers allowed a modicum of development of the zone largely in software and data processing related services. The origin of some of the software giants, and the PC manufacturers (once the import of processors and semiconductors were allowed in the nineties) that were to come later, lay in this zone, but the true liberation of the software industry from body shopping happened only since the era on large scale data transfer capability and data over cable, essentially the late eighties and the nineties. For much of the rest of Indian manufacturing the biases were too severe to allow industries like autoancillaries, non-electrical equipment, and nearly the entire organised industrial sector to export despite cost effective production ${ }^{7}$. Exports were therefore restricted to 'absolute" advantage industries much of it in the unorganised sector that used cheap and unprotected labour -diamond polishing, stone cutting, dirty chemical processing, handloom based textiles, ethnic products, products of nature, leather and handicrafts, and at the margin some light engineering based on exploitation of labour. Competitive industries could export very little in the face of the biases and the domination of world exports by the East Asian countries where the policy created strong biases in favour of exports.

\section{Labour Absorption in Zones}

When late industrialising countries embark upon their growth process, based on raising the investment rate in the economy, the condition that the added production of goods and services be cost effective and of a type that has an increasing market, usually imply inter alia the use of modern technologies. Unlike the traditional household technologies which have little potential to continually raise labour productivity by absorbing capital, modern technologies have that potential and hence the sin quo non of the late industrial transformation is the adoption of these technologies. But their adoption on a mass scale

\footnotetext{
${ }^{6}$ It was Singh, M. (1964), who drew attention to the collapse of exports in India over the late second half of the fifties and sixties during which the Mahalanobis Plan was vigorously pursued. Besides textiles where India had a share of the world market that exceed $15 \%$ which fell to less than $1 \%$, in many other areas handtools and light manufacturing, cycles, pipes etc, India's share nearly completely collapsed. The tragedy is that if there was one country that was ideally situated to take advantage of the falling tariffs under the GATT rounds from 1948 until 1973 it was India!

${ }^{7}$ A "suprising" result of a World Bank Study of the non-electrical machinery sector in 1984 covering the period of the early eighties was that almost all the industries it studied suffered from negative effective protection, and the domestic resource costs (DRCs) indicated that there were very efficient industries. World Bank (1989).
} 
does add to the problem of surplus labour. And all successful late industrialisers overcame that problem by very rapid growth which demands the quick raising of the investment level and its maintenance at a high level during the transformation phase. The demand side consistency for such a process was ensured both by high agricultural growth (nearly always engendered by land reforms in densely populated economies) and, as well by allowing external (export) demand to absorb labour directly even if such activities had little backward and forward linkages except through the labour income effect. The many early SEZs (then EPZs) in Taiwan, South Korea, Philippines, Mexico, Thailand, Singapore, China and Hong Kong must be seen as making possible this direct engagement of labour. (Morris, S. (1997); Morris, S. (2005)).

\section{Linkage Effects}

Additionally the pursuit of ELG was important to extend the advantage of such "zonal" activities by enhancing the backward and forward linkages and most importantly by making possible a steady supply of new industries (often developed in the 'hot-house' of import substitution a little earlier) for export activities both within zones and outside zones. In other words the pursuit of ELG by making possible exports of manufactures in a sustained way (not merely by exploiting existing factor cost advantages but dynamic comparative advantage) is what made possible the rapid growth (often called "miraculous" in the literature) of the zones and their vast spillovers on to the rest of the economy, and finally to this integration with the economy. Thus among the set of countries mentioned above while all adopted the policy of using zones to absorb surplus labour, those who did not adopt ELG (Hong Kong, Philippines, Mexico) could not grow as rapidly, to transform as the others which did (Taiwan, South Korea, Singapore, China from 1978, and Thailand). Hong Kong, in its reintegration back with China as China's open door policies took root, and given the metropolitan status of this city state, was nevertheless able to grow and transform . Its role was to provide capital and softer services for China's early phase of ELG, exploiting its locational and central place, governance and historical advantages of having specialised in higher order services.

\section{Indian Growth Strategy}

The contrast of these countries with India's import substitution was nearly total. The Indian approach was entirely supply oriented, with demand planned to arise from rising investments and from the agricultural sector. The Mahalanobis Plan (Mahalanobis, P.C., 1963) was doubly handicapped in absorbing labour and in ensuring sustainability of the transformation over the longer term. And the reasons for the same are not clearly understood even in the academic not to speak of the popular discussions. The most critical difference followed from the assumption of a closed economy from which all other differences followed. This meant that capital goods required for investment (as the rate of investment was to be raised) had necessarily to be produced locally denying the possibility of using the export of light manufactures to import capital goods. It necessarily meant that a rising savings rate had to be expended on a rising capital output ratio so that the growth that would be possible at any particular savings rate would be much smaller than in import substitution per se. In other words the push into heavy industries arising out of the closed economy assumption from the very beginning meant slow absorption of labour and slow growth in the initial periods, by design. This in the Mahalanobis Plan was sought to be "compensated" by investing in the household industries which it was assumed (based on the factor proportions in this segment) could 
deliver vast increases in both output and in labour use for small amounts of fixed capital invested in the segment. Clearly that there was an ascendant path (that could be determined by the planner) of gradual transformation and modernisation of household industries was also being assumed thereby. While a gradual process characterised the first and early industrialisations, given the existence of enclaved industries, and more generally of a ready shelf of technologies being available in the context of late industrialisation the Mahalanobis assumption was ahistorical and orthogonal (in this particular respect) to the late industrialisation process. This is also amply supported by the observation of Dennis Anderson (1984) and others (notably Ishikawa (1962)) that the household (barring a very tiny segment of the same which are able to change their processes or have favourable terms of trade) segment declines continuously as the industrialisation process take root. (Morris, S. 2001a).

The Indian economy went through distinct phases, the first was the phase of Planned Development (1955-1965), this was followed by the "phase of re-distribution" (19651979) wherein the state, given the failure of the plan to overcome unemployment, was forced adopt a vast array of de-distributive activities both symbolic and otherwise. But the failure of most of these programmes and schemes could have been anticipated. [No state has been able to overcome endowments failure of a large part of its population through programmes that mimic charity, but the one-shot redistribution typically in the form of land reforms, and investments in education have been eminently successful. Japan, South Korea, Taiwan, Singapore, Thailand are notable successful late industrial examples]. This second phase was one of very slow growth (approx. 3.5\% per annum) and this was followed by a phase more moderate growth (5\% per annum) in the eighties and the period of some what better growth (5-6\%) in the nineties following the reform of 1992-93. (Morris, S. 1997, Morris, S. 2002a).

\section{Ant-Export Bias and Early EPZs in India}

Given the anti-export bias of the Mahalanobis Plan, its bias against absorbing labour, and the non-implementation of land reforms, the potential to absorb labour was very little as was amply proved once the Plan came crashing (c.1964). The period from 1965 to 1979 which was one of slow growth -the so called Hindu Period absorbed labour at a very low rate (including in the modern small firms sector) that may not have even kept pace with population growth, thereby doing little to the problem of disguised unemployment even as late as the early eighties. Over the same period the use of EPZs to absorb labour in processing industries was denied by the overall policy that biased against exports and the lack of labour flexibility even in the EPZs. It was only in the eighties that some limited labour flexibility emerged in Mumbai and surrounding areas, as dysfunctional union behaviour began to give way to "economic demands" from labour. Only in the nineties can significant change in labour flexibility be said to have been realised. Only the Santacruz Electronic Export Promotion Zone (SEEPZ) being situated in Mumbai had some labour using activities, but the employment it provided was miniscule, largely because the macroeconomic and tax policies were about as biased against exports as could have been imagined, and none of these units could have used the vast and low cost labour from the unorganised labour market. (Morris, S. (2001a)). 


\section{Latin America’s EPZs}

In Latin American countries particularly in Central America and Mexico the zones became essentially 'maquiladora' industries that were based on relocation of parts of a value added chain of many manufacturing industries in the US that were particularly labour intensive or where the high labour safety and work place norms raised the costs of manufacture within US. Again these countries lacking the 'export -led growth policy' and the internal dynamism to carry through the transformation grew far more slowly and with wide variation in the rates than EA, and as such their zones did not play the extensive role that they did in East Asia. (Harris, N., 1990)

\section{African EPZs}

In Africa almost all the zones that came up were in response to preferential tariff arrangements under the Lome Convention and more generally under the Generalised System of Preferences (GSP), but most importantly the quota hopping behaviour of the successful East Asian exporters. Thus as in Mauritius the export zones were populated by garment firms from Korea, Taiwan and Thailand and elsewhere trying to get over the limitations of their quota under the Multi-Fibre Agreement (MFA) in the rich countries especially the US and EU. These could not take root in the deep manner the early "labour seeking” investments from the US and Japan in electronic and other labour intensive industries could in Taiwan , Korea or Singapore since the complimentary conditions for their spread and spill over effects were hardly there.

Principally, these relate to the conditions for growth of the home market and the nature of the state and its overall pursuit of policies that cohered little with bringing about industrial transformation. Thus in nearly all these countries the economic sizes were too small to allow meaningful import substitution and the initial diversification of the economy. In others (not necessarily small in size), the effort of import substitution was weak, uncoordinated and suffered from significant state failure, and were prematurely given up often under the tutelage of multi lateral agencies (MLAs). Similarly, the lack of a sufficiently robust agricultural transformation due in most cases to lack of public investments in agriculture and insufficient protection, limited the scope of the home market to provide sufficient impetus to the rudimentary industrial sectors. Even when there were regional agreements they were far too feeble to make any difference. Larger countries - Nigeria and Congo which had the best prospects were also subject to the vast capital flight which may have been as high as 4-8\% of GDP. (Lensink, R., N. Hermes, et al. (1998); Ndikumana, L. and T. Hall (c2000); Duwendag, D. (1988); Lessard, D. R. and J. Williamson (1987)).

Almost all of them had overvalued currencies and export hurting policies so that whatever little of the simple manufactured exports that could have taken place did not ${ }^{8}$. Lacking therefore either the impetus of the home market though consolidation of size, agricultural growth or public investments or of the external market, industries remained enclaved generating rents and transfers than further investments. SEZs therefore could hardly have been expected to play any significant role in these economies. In countries

\footnotetext{
${ }^{8}$ Natural resource exports and associated FDI to extract the same, whose determinants were of course very different could and did take place. But these had hardly any linkages, and with incomes arising largely in the form of rents and profits to foreign capital, the spending multipliesr effects would have been limited to wage incomes generated by FDI.
} 
that had inherited a certain regional centrality due to the location of cities of higher order (Kenya because of Nairobi, Nigeria because of its many large cities the special zones played an additional role in the weakly developing internal division of labour within the region /continent. This role was much larger and may have predominated in Latin America. FDI among Latin American countries was driven by the need of transnationals to optimise their activities across the region as intra-regional tariffs came down and regional agreements were forged. (Vaitsos, C. 1978).

\section{Problems of State and Class in Africa}

At the core the problems of Africa may be characterised as arising out of the class structure that these countries were left with in the post independence period (as for instance in Uganda and Kenya) and the essentially limited nature of the responses to overcome the same (as for instance in Tanzania). [Leys, Colin (1975), Mamdani, M. (1976), Shivji, Issa (1976)]. The countries with rich natural resources in these circumstances were subject to political and other kinds of involvement by multinational corporations (MNCs) (oil companies in Nigeria, Belgian and other mining interest in Congo for example). And when faced with either kleptocratic regimes or corruptible regimes, the rents from the mineral wealth could only lead to vast income inequalities, often strife, and to capital export. This is in sharp contrast to the nation building process and public investments that resulted out of the oil, gas and timber wealth of Malaysia, or the rice surplus of Thailand with their functional states. At still another level the initiatives correcting endowment failure - universalisation of education and skill formation through state initiative, and land reforms were not pursued in Africa, so that home markets and their growth could play only a limited role. And in many cases substantial numbers of their people were left outside the markets - to leave the problem of systemic poverty, to be 'addressed' (ineffectively of course) through micro-action by NGOs and charity from richer countries.

\section{Erroneous Policies of MLAs}

Compounding these problems was the role of the multilateral agencies (MLAs). As these countries ran into balance of payments problems (arising mostly out of capital flight and associated overvalued currencies ) and the attendant inflation, MLA imposed upon them orthodox currency depreciations and fiscal tightening. Currency depreciations did not work in the many countries whose exports consisted on a few natural resources, since their economies were hardly diversified, and even further liberalisation of the capital account to feed capital flight ( Cf. Lensink, R., N. Hermes, et al. (1998)). Fiscal tightening especially when they resulted in decline of public investments did not result in the rise of private investments. Under a policy that encouraged open capital account or turned a blind eye capital flight (arguing that these arose out of the poor macro economic policy) not recognising its endemic character surpluses generated in the growth process could hardly be fully retained and invested domestically. The dismantling of import substitution in almost all these countries was far too hasty. Similarly agricultural liberalisation has placed many of these countries with much agricultural potential at the mercy of imports (highly subsidised by much of Europe and the rich countries (other than the Cairns group possibly)). In violating the basic tenets of late industrialisation these countries do not as yet have a sustained engine of transformation and as such it is little wonder than their SEZs have been confined to the role of supplying in a small way to the rich countries under preferential arrangements. 


\section{SECTION 3: SEZs IN CHINA CONTRASTED WITH THE INDIAN CASE}

In contrast the role of SEZs in China (and earlier in Korea) has been stupendous, with as much as $30 \%$ of its exports it is estimated arising from SEZs. SEZs in Korea and Taiwan being important earlier now contribute little, since the countries as a whole have turned ELG. Being small in size the natural role for the SEZs would be to wither away as the salient features of the zones and their working were embraced by the rest of the economy. In China too we should see a decline in the relative role of the SEZs as the economy as a whole gets driven by markets and the ELG works to transform the economy. But the administrative declaration of many new fast growing areas - Shanghai, the interior the Machurian border etc as SEZs masks the decline of zones when functionally defined as special and in many ways shielded from the rest of the economy.

\section{Early Export Zones in China}

After the Sino-Soviet split in 1960, the Chinese economy whose trade ratio especially on account of imports had risen to moderately high levels under the various loan and technology transfer agreements, witnessed a fall in the trade ratio. In response to the exports having declined to a near autarkic level of $2.5 \%$ of GDP, the Chinese government set up several ECPBs (Export Commodity Production Bases) both along the coast and the interior, c. 1963. But overall macroeconomic policy had turned deeply against the production of export goods specifically during the period of deep import substitution. Therefore the lack of success of the ECPBs was only to be expected despite the active interest of the state to ensure their success. (Guangwen, Meng (2003). After the mess of the Great Leap Forward 1957 to 1962, the first ECPB was established in 1963 and several others were set up during the period up to 1978, including the Foshan City ECPB near Guangzhou in 1973. "They were granted a higher priority status in or preferential access to development capital, transportation, raw materials, electricity, and reduction of import duty for export production input accounting to their ability to meet contractual obligation”. Guangwen, Meng (2003), Their limited success was nevertheless of crucial importance in allowing the Chinese economy to import basic machinery and other capital goods from capitalist countries to make possible the import- substitution programme, from 1963 to 1978. This period of import substitution had been interrupted by the masochistic Cultural Revolution (1967-72) and the quick recovery from the nadir in China's trade ratio in 1971 (5\%), with exports being as low as 2.5\%, to between 9 and $10 \%$ in the by the mid seventies were enabled by these ECPBs.

The Chinese import substitution may be seen as having taken place between 1950 and 1957 and then from 1972 to 1978. Unlike in the Indian case of import substitution from 1955 to 1965, the importance of exports to finance the importation of capital goods was recognised in China, (the retreat into obscurantism during the Cultural Revolution and the Great Leap Forward apart). In India it was only during the eighties that earning foreign exchange rather than merely saving foreign exchange were seen as being relevant. Thus statements of a "unit of foreign exchange saved is worth a unit of foreign exchange earned" by planners and economists alike tightened the noose around the economy. And the low growth over the late sixties and the early seventies may in part be attributable to the lack of foreign exchange for even such small items but of much importance like 
crucial instrumentation, critical inputs like even grease! Deng Zio Ping was in charge during a brief period in 1975 . He was nevertheless able to impart his idea of riding both import substitution and export promotion. This was exemplified in the increasing role of ECPBs - a prelude to the export led growth strategy since 1978 once Deng was able to reassert himself from the end of 1978.

In contrast the early success of India's important substitution (the Indian economy at the close of 1965 was perhaps the most diversified economy outside the developed countries) made the through going re-examination of the strategy intellectually and politically difficult despite the years of stagnation and low growth that followed from 1965.

\section{Indian and Chinese Import Substitution Contrasted}

An important distinction between the Indian import substitution and the importsubstitutions of all other countries (except perhaps the Soviet Union's) was the twist provided by the Mahalanbobis Plan. Much attention has been drawn to the high tariffs and the 'protectionism' as also the "licensing raj" and their dysfunctionalities. But perhaps more than all these the idea of import substitution and growth under the closed economy assumption from which followed the logic of high investment in the k-goods sector from the very beginning as determining the ultimate growth of the economy (the so called heavy industry bias of the Mahalanobis Plan) was unique. This analytically implied small growth rates in the first ten years increasing thereafter and had no parallel with other plan models of transformation. It is this rather than the import substitution per se that greatly reduced the growth once the option of rising investments to create the market for capital goods was exhausted and the high costs of making all capital goods inhouse had to be borne. More normal import substitution (without a closed economy framework) which was followed by China (except during the excesses of the GLF and $\mathrm{CR}$ ) is not essentially self limiting. In itself such normal import substitution in potentially large economies have resulted in the industrial transformation - as exemplified by the US, and Germany in the nineteenth century, and Japan in the late nineteenth and early twentieth centuries.

\section{Regional Development Excesses}

Regional development excesses marked the Chinese development almost until 1978. The Plans in China started with the idea that the interiors of China Proper, should be the target of the bulk of the public investments and as much a $67 \%$ of the investments may have been so regionally directed even before the Sino-Soviet split. Since the split an additional reason - to ensure security of investments by locating them away from the borders further enhanced the bias towards the interior. This obviously resulted in the net material product of the interior increasing even though in the first decade and a half the interlinkages between these modern industries and the surrounding economic activities were hardly there. As such these large public investments' positive role may have served to create an enclaved modern sector in the interior. It is quite certain that the coastal areas which were the recipients of more than $70 \%$ of domestic investments in the pre-plan period c.1949. (Guangwen, Meng (2003)) could if built upon by planning and import substitution have resulted in a more efficient spatial distribution of industry. 


\section{Labour Use Differences}

A large price would no doubt have been paid in terms of the costs of these measures, since the network and agglomeration effects of locating closer to the coast which already had more than an enclaved growth had to be denied. And the large transport costs to interlink centres of investment in the interior as also these locations to the coast has to be undertaken simultaneously with the investment. Since even in this period the strategy of using idle labour (in a Lewisian sense) through mobilisation was at the core of the Chinese effort the real economic cost (not human cost) may not have been large despite the excesses arising out of "balancing" economic development. On the other hand in India the more modest regional development efforts being based on freight equalisation and without any explicit administrative strategy to use idle labour would have paid high fiscal and economic costs. The Mahalanobis Plan sought to use idle labour through restrictions capacities freezes on the large consumption goods sector, and promotion of small firms rather than trough mobilisation. This was counter to the industrial evolution of late industrial countries and resulted in severe biases against sectors that were most competitive, and as such were doomed to result in no more than a diversification of the economy. Furthermore, land reforms were a crucial requirement of the Plan in India since it was based on a supply (rather then demand) constraint assumption. Unfortunately, while this was realised in the Plan the land reforms as envisaged in the Avadi Congress Resolution were not carried out. China in contrast never had to face a home market constraint. Since the endowments problem was overcome under the egalitarian of common. So was the case with Japan, Taiwan, and South Korea all of which carried out land reforms (Morris, Sebastian 2001a)) to overcome the agricultural constraint.

\section{Imitating the "Little Dragons"}

The period from 1978 onwards up until almost 1990 with its very rapid growth resulting from imitating the East Asian Dragons' trade and macroeconomic policies, served to accentuate the difference between the coastal areas and the interior. This is despite the fairly large fiscal transfers and the attempt of the centre to support investments in the interior. Since 1990 the emphasis was on opening up other "growth axis" along the Yangtze river going all the way to the great city of Chongking and beyond, the areas along the Longhai-Lanxin Railway and border growth areas along the Korean side, the ASEAN Side bordering Vietnam and the Western Side bordering the Central Asian Countries. Of the latter border areas the developments along the ASEAN and Korea were more important given the greater dynamism and ELG policies of the neighbours. In all these new 'growth-areas' Special Economic Zones played a major part. Guangwen, Meng (2003). Over the nineties in response to these initiatives the differences between the Coast and the interior began to slowly decline through there never was very large income differences. (Zaing, Jie and Gustav Kristansen (2001)). The point to note here is that SEZs were an important element in the growth process, and in the policies that sought to direct and manage the same. In concentrating the growth potential of the interior and the border areas into the defined zones, the Chinese strategy was to take advantage of the agglomeration and other locational economies, besides the administrative and infrastructural efficiencies possible in the zone based development ${ }^{9}$.

\footnotetext{
${ }^{9}$ Much the same happened more under market forces as the US polulation were drown to the pheriphery the East, around the Great Lakes, the Western sea board and the Southern Sea board, as industrialisation tok root.
} 


\section{SECTION 4: \\ PHASES IN CHINA'S SEZs}

Concerned scholars of Chinese SEZs have seen many phases in the development of the approach to Special Zones. From the development of zones adjacent to cities mid sized and small, in the Pearl River Delta in the very early phase post the Open Door Policy (1978) to the phase of high tech and specialised zones that are being promoted today. The idea of zones, after the remarkable Pearl River Delta success and the success of ELG more generally was extended geographically, and also resulted in the increased size of the zones themselves, extension from processing zones to cities, to areas encompassing export production activities, and to large territories such as Hainan Island itself. They have also been extended along easy communication routes -river valleys as along the Yangtze and the railway into the central interior (Longhai- Lanxin) and along borders which we have already seen.

\section{Pearl River Delta Development}

The development of the Pearl River Delta area is a fallout of the one country two systems approach of the "open-door" policy that the post Mao regime put in place. (Victor F. S. Sit and Chun Yang (1997)). The idea that the fruits of international trade and foreign investment could be realised without having to change the essentially state administered communist system led to the creation of special areas to which foreign investors could be directed. The investments began to take root only in the early eighties and that too only in engaging migrant labour of the skilled and semi skilled variety. The FDI flows largely from Hong Kong and Macao based Chinese firms (some of which could have been 'benami' firms controlled by the newly emerging Chinese business elite) became a flood to swamp the developments in the region. While the micro level actions of the state and the provincial -Guangdong governments besides the local municipalities have been highlighted in the development of the special zones what is under emphasised in the literature is the coherence with the national level policies and the situation in HK and Macao. Thus the principal aspect of the opening up in 1978 itself as the massive support to exporting as an activity. This was done in the first instance by allowing public enterprises to export whatever they could. They could keep part of the exchange earned to import goods and sell in the domestic market. This part convertibility on the current account allowed the public sector (including the trading firms) to leverage the massive import repression to make exports lucrative.

Later any Chinese unit exporting could keep a part of the foreign exchange to use the same to import items of great local value. The incentive this provided to Chinese exports in relation sales in the domestic market were considerable and the country registered export growth in excess of $25 \%$ over the next five years. The limitations of this approach were being realised even then, since it was obvious that entry into items like textiles and garments light engineering and electronics assembly required import liberalisation at least in so far as the inputs to these industries were concerned.

In the next phase steep devaluation of the currency, and import liberalisations maintained high export sales profitability in relation to domestic sales profitability. 
Continued success of China was dependent upon the introduction of newer technologies, designs and the marketing links all of which were lacking among Chinese firms given the centralised and 'autarkic' development of the past. Foreign direct investment was seen as the basis for the transfer of these competencies and since the bulk of the economy was still under centralised planning with limited role for markets, the need for zones within which would be limited the capitalistic activities to earn foreign exchange had been arrived at, as a political 'compromise'. The very large and structural devaluations of the currency effective for exports in China gave to the process of industrial relocation (and then location) of activities from HK and Macao initially and then from Taiwan, Korea and Japan the basis for the sustained expansion of manufacturing exports from China at rates in excess of 20\%. (Sung, Yu-Wing (1991)),

\section{Role of Hong Kong and Macao}

It also coincided with the need for Hong Kong and Macao (actually of its Chinese trading businesses including the manufacturing enterprises) to venture out to cheaper locations. This need was stronger for HK and Macao rather than Korea and Taiwan since the latter countries had preceded or accompanied their export led growth with deeper import substitution thereby creating a vast array of manufactured goods which could be exported, even as their comparative advantage declined in labour intensive goods as incomes rose. In other words the policies of these ELG countries created the basis for unfoldment of dynamic comparative advantage ${ }^{10}$, which could continue to take through the transformation without any interruptions. HK and Macao with laissez faire policies were limited largely to their initially given comparative advantage and so the opportunities to set up labour intensive manufacturing in Thailand (which had also successfully imitated the first generation of ELG countries) was important. The opening of the Pearl River Delta area gave the glorious opportunity for HK and Macao firms to continue in labour intensive manufacturing especially of textiles garments and electronic assembly. The shortness of the distance despite the international border was important as also the revival of links with Chinese of a previous generation and the new business elite (largely derived from the party leaders) and the Chinese local governments. But perhaps the most important of all were the availability of a dedicated non-unionised working class, well trained and willing to work on incentives. Wage costs were ridiculously low given the extreme undervaluation of the Chinese currency. An added and necessary factor was the ability of the Chinese government both central and local to adhere to their commitments in terms of infrastructure, labour supply insulation from local controls, and freedom to import. The tax concessions and other fiscal concessions were important. The need for HK, Macao and soon enough Taiwanese firms to overcome quotas on their exports to the advanced countries given the Multi Fibre Agreement were contributory factors. As Chinese locations proved to the very lucrative for such labour seeking foreign investments, a flood of investments followed that went beyond textiles and related items to consumer electronics light engineering, and to regions outside the zones, and to areas outside the Pearl River Delta.

\footnotetext{
${ }^{10}$ The notion of dynamic comparative advantage unfolding was propounded by Lall, S. (1984) for the East Asian industrializations and by Ozawa, T (1979) and Kojima, K. and T. Ozawa (1984) for Japan, and for East Asia in the abetment of their industrializations through FDI and other non-equity links from Japan. The “flying geese' phenomenon of the successful ELG countries was an early description of the same by Ozawa op.cit. The Lizstian arguments against Adam Smith's Wealth of Nations, and the understanding of the 'infant industry' argument are its precusors.
} 


\section{'FDI' into the Pearl River Delta Area}

The extreme dynamism of the exports from the zones in the Pearl River Delta led to "FDI" from HK and Taiwan to small and mid sized towns and cities in the area including in the Shenzen zone. This was supported by the rapid infrastructural upgradation of the destinations of FDI, allowing a hierarchy of central places that placed HK at the centre, displacing Guangzhou the primate city in the region. Victor F. S. Sit and Chun Yang (1997). Indeed Guangzhou itself had displaced HK which had been the primate city during the long years of close door development from 1950 to 1975, a period during which the trade links of HK with China had steadily come down. Therefore, the FDI from HK. Macao and Taiwan, especially the latter must be seen as the beginning of reintegration of the Chinese economy with the world, the reestablishment of the primacy of Hong Kong and bringing back (to create) the foundations for markets and the competencies for dealing with the rest of the world which had been left to flourish in HK.

Beyond all the situational geographic and political factors, stood the economic. In undervaluing its currency and in explicitly supporting exports the reality of Chinese labour being available at very low price (its true price owing to 'Unlimited' supplies of labour in a Lewisian sense) but now to the whole world through exports was the core reason for success. And this policy is easily emulated. In that respect China was only following the 'flying geese' fashion the export led growth economies - Korea, Taiwan and Thailand. (Morris, S. 1997, Morris, S., 2005). Its much deeper import substitution given its large size and the policy of self reliance under communist government, allowed that process to go on from producing garments and textiles to practically every item of manufacturing. The massive redistribution of incomes and assets under the communist regime, as also the fact that basic health and education had been achieved in a universal way, had created a society with near equality of income distribution and corrected the endowment failure. That allowed the home market to expand vigorously based on the demands created by the spending out of labour incomes of the massive employment that export industries in zones created. Of course Chinese incomes are diverging rapidly but given that it started with very little inequalities, it remains one of the most egalitarian societies, which is best confirmed by the commodity pattern of its demand. (Morris, Sebastian 2005).

Growth outside the zones, and spillover benefits outside the zones especially in terms of learning to work with high technology and modern designs, and with modes of contracts (Original Equipment Manufacture (OEM), International Subcontracting (IS), Contract Processing etc). These have been crucial as the organisational and contractual basis for the high growth and transformation of the Chinese economy.

The FDI that went from HK and Macao to the Pearl River Delta has been quite unlike FDI as observed elsewhere. Sit and Yang (1997) observe that this FDI was export oriented almost in its entirety. This is not surprising given the export led industrialisation policies that China was following quite like South Korea and Taiwan in and earlier period. Even in these countries much of the FDI (and more importantly non-FDI forms that led to OEM and IS relationships) was export oriented. The contrast with nearly all other LDCs (other than the ELG economies) where FDI was host country market serving (Latin America, South Asia) or resource extraction oriented (Latin America, Africa, Indonesia), is glaring but not surprising given the characteristics of ELG. Equally importantly they also observe that FDI at least in the Pearl Delta Area was directed to 
smaller towns and cites rather than to the primate city which actually suffered a decline. Given the nature of the industry- labour value addition with much of the further up softer factors (trade, wholesaling, designs, marketing) being realised in HK and Macao this was not surprising, either.

The efficient provision of infrastructure in the zones and the choice of the zones away from the main city (for political reasons of living up to the idea of two systems in one country) but closer to smaller cities with the trained manpower were additional factors were important in the unlimited expansion of the original zone. So also the controlled immigration into these areas, expansion possibilities within the zone and the extreme profitability of exports based on labour processing. If one views the relationship between HK and Macao and China as one of re-absorption into the Chinese economy, of these city states even as they re-establish their urban rank order in the hierarchy of central places, then there is no anomaly to the expectation that the bulk of FDI (generally assumed to be home market seeking) get quartered in and around the major cities of a nation especially its primate city.

\section{Box: Regional Determinants of FDI ${ }^{11}$}

“An interesting starting point is Stephen Hymer's (1971) understanding of the location of activities within the globally present multinational corporation. Hymer following the early business strategy approach classified decision making into three kinds: operational, managerial and strategic. This classification has now become standard in the study of organisations and their strategy/ structure/ decision making. Strategic decisions where much discretion and value arises are housed in the head quarters (HQ) of the firm which for various organisational and economic reasons (span of control, availability of a wide variety of services locally, the possibility of being in close communication with other managerial hierarchies, the lower costs of a central place to direct and manage businesses from) tends to get located in the primate city of the source country. And source countries are those with primate cities in the global sense. (And the rise of MNCs in a particular country strongly catapults its primate city to a higher level in a global sense). While some of the administrative / managerial decisions could take place at the subsidiary level, they locate in the second order cities of the world which include the leading primate cities of the non-industrialised countries. The operational decisions covering the day to day aspect of production could be located in many more central places, and therefore could be more widespread in a spatial sense. Thus an important insight which was crucial to regional scientists - the hierarchy of central places, and the varying central place needs of various industries /activities, can be exploited to understand the regional choices of FDI firms or MNCs. The HQ functions of the MNCs having the highest need, and MNCs activities in other countries competing with the national firms of host countries for locating their offices for strategic decision making, would tend to successfully locate close to the most important cities. In other words MNCs' need for central places is even larger than that of non-MNC firms, ceterius paribus. This is easily related to the 'intangible asset' theory of MNC or the 'advantage theory' (Kindleberger, 1969) which conceptualises that MNCs need to have an advantage (ownership) that is not easily traded in the market, so that they need to internalise the same to exploit their ownership advantages globally and they do so in countries with the

\footnotetext{
${ }^{11}$ From Morris, S. (2004).
} 
best locational factors. This is the ownership, location, internalisation (OLI) framework, which is the mainstream conceptualisation of FDI/ MNCs. (Dunning, J., 1979)

\section{The Locational Choices of MNCs}

MNCs need to have a distinct advantage so that it can overcome the intrinsic disadvantage of operating at a distance in a country that is different from its home country. Focussing first on the additional cost to the MNC in operating in a foreign country, it is obvious that risks especially those that arise out of political changes and uncertainties in the law in business, threatening events like riots and revolutions, discretionary rules, and regulatory uncertainties when they are large become asymmetric as between MNCs and local firms. This in an intercountry context implies that MNCs could bypass countries with large risks in spite of possibly other good economic factors. In the intracountry context (especially in a large federally constituted nation) this means that regions that show adverse political and social characteristics would be severely punished by foreign direct investors.

Lower order cities are more distant from foreign cities and home country primate central places on the aspect of living spaces, and availability of goods and services of a wide variety, as compared to the largest primate cities of the host developing country. Thus lower order cities would have a comparative disadvantage to house FDI vis-à-vis domestic investments, so that FDI would be far more concentrated in the highest order cities.

MNCs operate at the national and international (as when they export) levels, and hardly ever at the regional levels. This means that their need for central places and ability to afford the same is comparatively higher for them than for nationally limited and certainly regionally limited businesses of similar products and sizes. This larger comparative need is perhaps the biggest driver of MNCs towards the primate and most well served cities in an economy to locate their (host country) HQ and offices. And then locating the actual plant /producing offices etc would be conditional on this choice especially when the outputs planned are not constrained by dependence on geography (natural resources etc). In other words FDI would rank highest in the need for central places of all investments. The lowest ranking would be investments by small local firms and investments without scale and scope economies and with large costs of movement of good and services typically retailing, vegetable sales, repair services etc. If the actual production is not characterised by a need to be near a particular resource or near markets, then it would be concentrated in the outskirts of the city selected for HQ, or in nearby smaller towns. If on the other hand the investments need to be near particular resources, then that factor would dominate the locational choice and the MNC may make do with the highest order central city or the city with the best serving functions near the resource. When production needs to be closer to markets (e.g. retail chain stores, oil distribution, food chains), then the investments would be distributed across the country with the HQ being located in the primate /best city. In the special case where the activities of skilled people constitute the bulk of the value added (software, $R \& D$, biotechnology, IT, telecom and electronics equipment, precision machinery) besides central place functions, good living conditions and spaces- city serving functions- would predominate. And in all cases there would be additional bandwagon effects following from the agglomeration economies. These are very large in service industries of the IT and software type. 
Intangible Assets and Central Place Requirements

Now FDI presumably having a comparative advantage in intangible asset industries would tend to operate at national and international levels, in order to maximise the gain from intangible assets, since there are no diseconomies to reputational assets such as brands, technology, skills and trade secrets. Indeed the very reason for transnationalisation of MNCs is to exploit the largest possible markets through internalisation (since markets for such intangible assets either don't exist, or undervalue such assets). Thus given the prior transnationalisation of MNCs we would be almost never wrong in presuming that MNC in the host country starts with the intention of accessing the entire national market. ${ }^{12}$ ",

Technology based industries were deliberately promoted after the spectacular success of labour intensive manufacturing in the late 80s and early nineties in response to rising land costs and the declining comparative advantage of the coast vis-à-vis the interior which was beginning to be felt. Other fiscal incentives were also important to make the transition to the technology and skill intensive phase of growth. (Wei, Xie (2000)).

\section{Three Phases in the Development of Shenzen}

Three phases can be seen in the development of Shenzhen which is the locational expression of the macroeconomic patterns of China's trade and inward foreign investment as its comparative advantage was allowed to unfold in a dynamic way through ELG policies. The original objects of SEZs were attracting foreign capital, importing advanced technologies, employment of Chinese workers, understanding management of capitalist enterprises. The employment of Chinese workers was the objective that was more than met and became a driver of success, since with the vast employment growth and the spending and transfer effects of the same, the country could look ward to demand as well as foreign exchange to step up the rate of investments. That the employment happened among the working class of no distinction and among women more than men also meant that the vehicle of the SEZs could only have become increasingly popular. The macroeconomic consistency in terms of the pursuit of the ELG of the Asian dragons was crucial. It is only now after much of the disguised labour has been absorbed that the aspect of high technology comes to the forefront. Similarly, the aspect of foreign investment was less foreign and more local. But the investments may have been more domestic than foreign. A Lewisian model where the quit rate wages from the noncapitalist sector does not rise (or rises much slower than labour productivity) is at the core of the understanding of the rapid rise in savings and investments of the Chinese economy. The vast investment in public services and little or no unionisation meant that the real wages would rise only once all disguised unemployment is over. Use of migrant rather than local labour was crucial to the large rise in the savings and surpluses of the relocated labour intensive industries. And the demand side was taken care of by the undervalued currency and the slew of measures that favoured tradable goods production, import substitution and export promotion.

\footnotetext{
12 This may not be true for MNCs from small countries in an enormously large market like the US, where MNC firms may chose a niche strategy. But there are very few cases where the niche strategy would translate into a local market strategy. More typically it would mean a niche product or service for the national market as a whole.
} 
Unlike what is generally believed the regional inequality in China in income and growth are not very large and indeed strong convergence has taken place both within regions and across regions with some significant exceptions. Anhui Province witnessed stagnation in per capita income due to natural calamities. (Zhang and Kristensen, 2001). More importantly the inequality of foreign direct investment both within and across regions is considerable but that has not led to rising inequality of incomes. This is because Keynesian demand multiplier effects which have been large for the poorer areas have been at work in various ways acting through the demand side effects of the rise in income and spending in the FDI rich areas. (Zhang, Jie and Gustav Kristensen (2001)).

In 2000 the idea was "Western Development “, i.e. to bring the interior of China into the development. Equally importantly the activities within the zones had themselves diversified as Chinese exports have diversified into technology based exports from manufacture of simple labour intensive goods, assembly etc. As imports of goods of high tech, and capital goods took place their import substitution also began in some of these zones. Indeed the state is today focused on pushing the zones and areas around zones higher up the value added chain and onto high skill labour using activities to serve both exports and import substitution. This is as to be expected since the disguised unemployment may have been completely overcome by the mid-nineties when the labour shortages emerged and the need to take industry to the interior became obvious. Labour rates also began to rise steeply in the East making vanilla semi-skilled labour absorption no longer as highly profitable as they used to be in the first half of the eighties. Today the state in engaged in promoting various high tech parks close to large cities and to population centres, including in some of the earlier highly successful manufacturing zones. These too have registered much success since in many other ways and especially structurally the Chinese economy having entered the middle income group is at the beginning of the expected rapid growth of high tech and differentiated goods industries. The deeper import substitution of the Chinese economy and its large size would permit such growth into a wide variety of industries and services. In this respect China today is where Korea was in the early to mid-eighties.

Not many Chinese firms were headquartered in Shanghai. But over the late nineties Shanghai has emerged as the preferred location of foreign (truly foreign) firms in the Chinese economy. The vast investments in the city serving functions by the Chinese and municipal governments, besides the development of the various levels of zones have been instrumental in this transformation. Being also close to the centre of gravity of the Chinese population, and having excellent links with other centres of population besides export oriented manufacturing, manufacturing for import substitution by computer and electronic firms, precision engineering, high technology firms, automobile, electronic, telephone equipment, etc have taken root in Shanghai. A critical level of foreign (expatriate population) has allowed the city to be comfortable for foreigners especially the Japanese.

\section{Shanghai- Recapturing Primate Status}

he growth of the Zones in and around Shanghai, their large FDI inflows and the support to Shanghai from the central government, and its miraculously rapid transformation must also be seen as the re-establishment of the hierarchy of central places with Shanghai in the lead of the entire hinterland of the city, and perhaps the most important gateway city of the country. As China opened up the reassertion of Shanghai was inevitable and the 
setting up of zones in and around Shanghai, and actions of the Chinese government must be seen as consciously or unconsciously (more likely) having led to an orderly unfoldment of the same. Thus Shanghai has quickly established its hierarchy and today the entire region including the subservient cities have been closely linked and coordinated especially in terms of road and rail links to make the hinterland access of Shanghai and its links with other cities very easy. Shanghai commands a hinterland that is one of the largest in world in both area and population since along the eastern board it extends up to Beijing and into the lower valley of the Hwang-ho, and along the Yangtze right up to Chengdu (China large city in the interior). (Wei, Yehua Dennis and Chi Kin Leung (2005)). The choice of Shanghai as China's primate city in the new world of globalisation was a recognition of its obvious geographical advantages and of policies and investments to take advantage of the same. Thus the infrastructural development along the Yangtze to make the river navigable almost $3000 \mathrm{~km}$ into the interior, the area and development approaches around the principal arteries linking the city to other cites in the heartland of China, the vast investments in city forming functions, the opening up of zones and areas within and outside the city for FDI and industrial location, besides the macroeconomic drivers of ELG must be seen together. To make a contrast, it is akin to imagining that there is acute recognition at the national level of Calcutta's position as commanding a vast hinterland and therefore making coordinated investments to vastly improve its links with all the second order cities in the Ganges basin even as all fiscal administrative and other dysfunctional stoppers are removed to the development of the region.

\section{'FDI' into Shanghai}

While the tight control and regulation over FDI and especially its direction to the earlier designated Zones were important factors in Shanghai being left out in the early phase of the open door developments, the macro economic aspect of the early phase is less recognised or realised. The first effective phase of exports from China was based on leveraging the import repression though state owned enterprises which had its limitation. In the second phase which overlapped the first the relocation of manufacturing from $\mathrm{HK}$ and Macao and its great expansion in the immediate hinterland of Macao and HK (the Pearl River Delta area) was the sine quo non of the early labour intensive phase of export led growth. Nearness to HK and Macao and the close links of the foreign investors (Chinese) based in the very same city states, were crucial. In later phases of ELG "true" non-Chinese foreign investment from Korea, Japan and the US emerged, but Chinese investments have always dominated accounting for as much as $80 \%$ of FDI. Indeed round tripping of China's own investments may have been the bigger part of this $80 \%$. Thus until recently while in the Pearl River Delta areas the role of HK was predominant by the late 90s the role of non- Hong Kong sources was more important in Shanghai. There was very little FDI into Shanghai in the eighties. FDI into Shanghai starts with the promotion of the Pudong industrial zone of Shanghai, and the extension of all concessions, large state and central investments into the city and the city being seen as a vehicle for the continuation of the industrial transformation of China. FDI Not only from HK (which source was dominant in the early nineties) but from other countries followed.

The Shanghai area attracted over US\$ 32 billion over the nineties much of it from 1994 onwards. Of these cumulative investments as much as 58\% came from non HK sources, which was very different from the early phase of FDI in China and from the experience of the Pearl River Delta Areas. In 2002 the source distribution was as follows: HK (24.3 \%) with Japan, US, Taiwan, Singapore, UK and Germany contributing as much as 63\%. 
Many of these investments took the form of wholly owned or majority owned foreign enterprises, and a larger proportion of these rather than of the HK sources were directed at serving the home market and possibly also of export of components of differentiated and capital and technology intensive goods, given the continues adherence to ELG polices in the nineties. (Wei, Yehua Dennis and Chi Kin Leung (2005)).

\section{FDI and Technology Imports}

Japanese FDI was perhaps the last to respond to the open-door policy of China, given the history of Sino-Japanese relationship. This is despite the high expected affinity given the small distance, the complementarities of the two economies and especially of their businesses the influence of Japan and especially of its FDI was of great importance to China in the un-foldment of its dynamic comparative advantage. The institution of the SEZs and OCCs were particularly comforting to Japanese FDI. Korean and Taiwanese investments as also investments from US and European countries were somewhat late in responding. SEZs and OCCs were initially important in the late eighties and the first phase of the boom over the nineties. As the boom in FDI from Japan took place the FDI was more generally directed as the country itself changed and the openness of China was extended beyond the SEZs. Japanese investments was of two types - one which was dependent on cheaper labour (though to a far less extent than FDI from Hong Kong) where the comparative advantage of the SEZs were still large. The more important technology based and skill based investments were more generally directed. Zhou, Changhui; Andrew Delios And Jing Yu Yang (2001). Trading investments by the Shogao-shosas were almost exclusively directed to the largest cities and higher order central places. The size of the local market in the immediate environs of the city /place attracting FDI were of no consequence, pointing to the strong ELG aspect of the Chinese economy and the export and import substitution (working on the home market at a national level) that were its two components having been the determinant of Japanese FDI. Rail connectivity, infrastructure in general and access to central place functions were important determinants. 


\section{SECTION 5: SEZs IN OTHER COUNTRIES.}

\section{Philippines}

The case of Philippines is interesting. Available evidence indicates that this early pioneer of special economic zones for export promotion after early head start did not do well at all. Early in 1972 after the collapse of the economic boom of the fifties and the early sixties, the government under Martial Law set up the Bataan Export Processing Zone on virgin territory at the southern tip of Luzon in 1972. Much expenditure was incurred by the government to build the zone and its infrastructure. Almost all the labour and manpower used came from the rest of the country. Since the government combined the objective of (regional) development with that of exports the high cost of infrastructure in creating this zone is only to be expected and cannot be an argument against the idea of EPZs per se. In about 6 years the zone grew with more than 19,000 direct employment in the zone by 1977 .

The principal industries were as is to be expected textiles, garments, shoes and other processing industries including some electronic assembly. The principal attractiveness arose out of the ease of working with the simpler administrative machinery within the zone, besides the duty concessions usual to export zones. Wage costs were apparently somewhat higher in the zone than elsewhere in Philippines since in the zone apparently labour laws were being implemented while elsewhere they could be readily violated. (Warr, Peter G. (c.1987)). Yet expansion did not go much beyond the initial phase of expansion. Unlike Korea and Taiwan, the Philippine industrialisation cannot be called ELG. (Datta-Chaudhuri, M. (1981)). It was more laissez faire with a modicum of import substitution, and as such the ready availability of new industries for exports as the earlier more labour intensive stages got spent was not there. Moreover being near laissez faire the export profitability could not have been higher than domestic sale profitability. Lacking therefore an export pressure the results are not surprising. The other interesting aspects such as the sourcing of as much as $70 \%$ of the capital used in the zone from the domestic market and institutions even by FDI firms in the zone can be reconciled with the fact that the government had artificially lowered the cost of capital for preferred industries by control over finance. This feature which is common to many countries including some of the ELG countries, could have been functional in resulting in heightened exports had the policy been ELG rather than merely liberal with weak import substitution. Since growth of exports with a base in the zone (or for that matter in the Philippines) was limited the high profitability of the investors including foreign investors did not result in reinvestments to expand greatly the operations but only to high dividends, or transfer prices between parent and affiliates to be fixed in a way as to remove the surpluses out of the economy. The overall capital flight from the Philippine economy has been large being closer to Latin American levels. The contrast with the East Asian on exports and growth is quite remarkable and the differences had been noted early by perceptive scholars. (Datta-Chaudhuri, M, (1981)). The Philippines experience illustrates that using EPZs to take advantage of the static comparative advantage of low cost labour are modest and self limiting unless accompanied by overall macroeconomic and industrial polices that make for the unfoldment of dynamic comparative advantage.

\section{Sri Lanka}

Sri Lanka too promoted export processing zones in the eighties. The performance of these zones has been far more significant for the Sri Lankan economy, than was the case of 
zones for the Indian economy, before the internal civil war destroyed or greatly arrested their potential during the nineties. Even at the peak in late eighties the success can be considered modest at best and there is really no comparison with any of the successful East Asian cases. Textiles and clothing dominated, and the activities were no doubt helped by the MFA which made many low end garment and textile producers from East Asia and India shift to Sri Lanka to exploit that country's unused quotas. Despite the returns being high in these zones, the return earned by domestic partners in JVs were high significant the expansion of activities in these zones was modest. (Jayanthakumaran, K. and John Weiss (1997)). Sri Lanka's economic policies were not ELG. Nor was import substitution consistently pursued, and the modest performance of its zones and their lack of diversification are therefore understood.

\section{Eastern Europe and Russia}

Many Eastern European countries including Russia after the collapse of the Soviet Union have attempted to follow China by imitating the SEZ idea. In Russia the objectives were many and these were highlighted in the debate to win political support for reform. And much discussion followed in both countries. But the results were quite different. In China while the economic aspects especially the export linkage overrode everything else, in Russia the SEZ idea became an important vehicle for usurping power away from the centre and to the local and state levels. Republicans and local governments particularly saw this as an instrument to wrest power from the Centre. Very quickly the motions were gone through and vast areas were declared as FEZs There are FEZs in 11 Regions covering over $1 \mathrm{~m} \mathrm{sq} \mathrm{kms}$ (about $7 \%$ of the area of Russia)! But performance has been no better than in other non FEZ areas. While the fact that over much of the 90s Russia was in turmoil is an explanation for the poor performance of the Russian economy and its FEZs, the neglect of the economic, organisational, financial and legal aspects of carrying out business in the FEZs were also important and as Russia has begum to return to normalcy this neglect now clearly stands in the way of the development of the zones. SEZs were also compatible with the "shock-therapy" approach of Russia's reform. (Manezhev, S.A. (1995)).

Perhaps the lack of anything like a coherent ELG of China is most notable. In Russia's case, given its near complete industrialisation under the Soviet system, the equivalent of ELG would have been the export of the articles and services based on the use of its highly skilled and educated labour from its territory besides products of nature rather than frittering away that advantage by exporting away such manpower to Europe and the US as has been happening. That would have required coordinated efforts in such areas as defence industries, electronics, metallurgy, avionics, computers and software and many high tech industries which were Russia's particular advantages. The aspect of learning management, designing organisations, creating incentive compatible ways of working in groups, financing and marketing were even more important in the case of Russia. This would have made the role of FDI into zones could have been crucial, if the effort had been concentrated in to a few zones under an overarching macroeconomic policy that was favourable to industrial location in Russia. The macroeconomics was as adverse as could be imagined. Capital flight under the confusion of the shock therapy approach reached more than $8 \%$ of GDP and remained at these levels for well over a decade. Indeed no orderly movement to markets was possible and the economy even now awaits the rule of law (especially in economic transactions) to emerge not just by the exercise of state power but by the power of mafias and robber barons as they begin to recognise the value of (and require) contractual rules for the conduct of business. 
In Eastern Europe on the other hand the function of linkage with Western Europe dominated the SEZs as much as the changing economic structure and performance of the economy. This happened on the accommodation of these countries either directly into the EU or through arrangements that improved market access. More than the special zones the entire economy was so turned around to the great economic benefit of the region. FDI into countries like Hungary was almost entirely dominated by industrial revival linked to the establishment of trade links and hence inter alia the export of manufactures to Western Europe. (Basant, Rakesh and Sebastian Morris, 2002).

\section{Conclusion}

This paper has argued that the role the SEZs and more generally special zones play have varied widely depending upon the strategies of growth their hosting countries have followed and the special trade relationships they have with other countries. The roles have also varied over time depending upon the trade strategy and more generally the growth strategies pursued by the countries, especially when these are not already industrialised. It is useful to distinguish between laissez-faire, import-substitution and export led growth as distinct types of industrialisations to understand not only trade and investment and growth but also the roles and success of SEZs across a wide variety of countries and over time in the second half of the twentieth century.

Special economic zones following the enormous success of China have been widely imitated. But it is to be entirely anticipated that the results would vary greatly. Earlier avatars of SEZs in the form of Foreign Trade Zones (FTZs) and Export Promotion Zones (EPZs) were important in the export led growth of East Asia especially South Korea. But more than SEZs or EPZs per se it is the pursuit of "export led growth policies" which underlie the success of exporting and hence of SEZs. SEZz/EPZs can be seen as a (not necessary) microeconomic and spatial initiative in the pursuit of ELG under rather special circumstances by China, and South Korea and Taiwan to more limited extent in their early phases of transformation. In other countries not pursuing ELG success of SEZs/EPZs has been rather modest. The roles played by the SEZs/ EPZs etc whatever their original purpose were constrained and determined by the macroeconomic policies, trade policies, and regional alignments. There is little meaning in studying SEZs beyond their layout and design without reference to these broader trade and macroeconomic policies. Thus early pioneers line India could make little out of their EPZs since the policies severely biased against exports. We characterise export led growth (ELG) as the strategy that has allowed the late twentieth century industrialisations, which is far from both import substitution (as conventionally understood) and laissez faire, and to be the simultaneous pursuit of both IS and EP. With this framework we are able to understand the role and evolution of SEZs in a wide variety of countries. These help us to explain and anticipate that unless the policy turns sharply to favours exports (more correctly tradables over non tradables) the success of Indian SEZs would be modest and nowhere near that registered in China. Following from our characterisation of Import Substitution, Export Led Growth and Laissez Faire we also bring out the nature and performance of "special zones” when these are promoted under the very same regimes.

The more analytical conclusions outlining the role and performance of SEZs were gathered together in table 4 . 


\section{Bibliography}

Adler, Johan. (2001), “China’s foreign trade reform 1979-1998 Policy measures and some important initial economic conditions”, Department of Economics, Göteborg University, mimeo March.

Alam, Shahid (1989). Governments and markets in economic development strategies; lessons from Korea, Taiwan, and Japan. New York, Praeger.

Altman, E. I. and I. Walter (1980). Transnational Conglomerates and the Economics of Dependent Development: A Case Study of the International Electrical Oligopoly and Brazil's Electrical Industry. Jai Press Inc. Greenwich, Connecticut.

Amsden, Alice (1989). Asia's Next Giant: Korea and Late Industrialisation. Oxford University Press.

Anderson, D. (1982). Small Industry in Developing Countries:A Discussion of Issues. World Development: Vol.10,No.11,pp.913-948,1982.

Baer, W. and K. Hargis (1997). Forms of External Capital and Economic Development in Latin America: 1820-1997. World Development, Vol. 25, No. 11, Nov. pp. 18051820.

Bhagwati, Jagdish (1988), “Export Promoting Trade Strategy: Issues and Evidence”, The World Bank Research Observer, Vol.3, No.1, Jan.

Chen, Jean Jinghan (1996), "The Impact of Public Construction Investment upon Special Economic Zones - The Chinese Experience”, Construction Management and Economics, Vol.14, pp. 175-182.

Datta-Chaudhury, M. (1981). "Industrialisation and Foreign Trade: The Development Experience of South Korea and Philippines”, in Lee, Eddy (ed.) (1981).

Ding, Daniel, Dail Fields and Syed Akhtar (1997), “An empirical study of human resource management policies and practices in foreign-invested enterprises in China: the case of Shenzen Special Economic Zone", The International Journal of Human Resource Management, Vol. 8, No.5 October.

Dunning, John, H. (1979), "Explaining Changing Patterns of International Production: In Defence of the Eclectic Theory", Oxford Bulletin of Economics and Statistics, 41, 1979, 269-295.

Duwendag, D. (1988). Capital Flight from Developing Countries. Economics: Vol.38, pp.26-59.

Eingereicht von Claus Knoth (2000), “Special Economic Zones and Economic Transformation The Case of the People's Republic of China Dissertation zur Erlangung des akademischen Grades des Doktors der Wirtschaftswissenschaften des Fachbereichs Wirtschaftswissenschaften der Universität Konstanz Konstanz, März .

Evans, Peter B. (1979). Dependent Development: The Alliance of Multinational, State and Local Capital in Brazil. Princeton University Press.

Frank, A. G. (1975). Capitalist Underdevelopment. New York, Oxford University Press.

Furtado, Celso (1963). The Economic Growth of Brazil. Berkeley and Los Angeles. University of California Press.

Ge, Wei (1999). "Special Economic Zones and the Opening of the Chinese Economy: Some Lessons for Economic Liberalization”, World Development Vol. 27, No. 7, pp. $1267 \pm 1285$.

Gerschenkron, Alexander (1966). Economic Development in Historical Perspective. Harvard University Press, Cambridge, MA. 
Government of Karnataka (2004), Expression of Interest Document: Hassan Special Economic Zone, Karnataka, January 2004.

Guangwen, Meng (2003), “The Theory and Practice of Free Economic Zones: A Case Study of Tianjin, People's Republic of China” Submitted to the Combined Faculties for the Natural Sciences and for Mathematics of the Ruprecht-Karls University of Heidelberg, Germany for the Degree of Doctor of Natural Sciences, Tianjin, People's Republic of China $14^{\text {th }}$ February.

Harris, N. (1990). Export Processing in Mexico (Review Article). JDS: Vol.27, No.1, Oct., pp.118-125.

Hymer, Stephen (1971), “The Multinational Corporation and the International Division of Labour”, Chapter 6 in The Multinational Corporation: A Radical Approach (Papers by Stephen Hymer) ed. by Cohen et al, Cambridge Univ. Press, 1979.

Ishikawa, Shigeru (1962), “A Comparison of the Size Structures in Indian and Japanese Manufacturing,” The Hitotsubashi Journal of Economics, Vol. 2, No. 2, March.

Jayanthakumaran, K. and John Weiss (1997). "Export Processing Zones in Sri-Lanka: A Cost Benefit Appraisal”. Journal of International Development. Vol.9. No.5., pp.727-737.

Kindleberger, Charles P. 1969. American Business Abroad: Six Lectures on Direct Investment", New Haven and London, Yale University Press.

Kojima, K. and T. Ozawa (1984). Micro- and Macro-Economic Models of Direct Foreign Investment: toward A Synthesis. Hitotsubashi Journal of Economics: Vol.25, 1984, pp. 1-20.

Lall, S. (1994). "The East Asian Miracle: Does the Bell Toll for Industrial Strategy?: Review of the World Bank's East Asian Miracle Report”. World Development, Vol.22, No.4, pp.645-54.

Lee, Eddy (1981). Export Led Industrialisation and Development. International Labour Organisation, Asian Employment Programme, Manila.

Lensink, R., N. Hermes, et al. (1998). The Effect of Financial Liberalization on Capital Flight in African Economies. World Development /Vol 26 \#7, July 1998.

Lensink, R., N. Hermes, et al. (1998). The Effect of Financial Liberalization on Capital Flight in African Economies. Great Britian. World Development /Vol 26 \#7, July 1998.

Lessard, D. R. and J. Williamson (1987). Capital Flight and the Third World Debt. Institute for International Economics, Washington DC.

Leys, Colin (1975). Underdevelopment in Kenya: The Political Economy of Neocolonialism". Heineman, London.

Liang, Li (1999), "Foreign Investment, Economic Growth and Temporary Migration: The Case of Shenzhen Special Economic Zone, China”, Development and Society, Vol.1, June.

Liang, Zai (1999). "Foreign Investment, Economic Growth, and Temporary Migration: The Case of Shenzhen Special Economic Zone, China”. Development and Society, Vol.28, No.1, June, pp.115-137.Migration rates related to FDI, The sex ratio ix very much in favour of female. Temporary migration is no longer an effective control; Male employment has fallen short; Sustainability requires the movement up the value added chain.

Little, I.M.D. (1981). “The Experience and Causes of Rapid Labour Intensive Development in Korea, Taiwan Province, Hong Kong and Singapore and the Possibilities of Emulation”, in Lee, Eddy (ed.) (1981). 
Mahalanobis, P. (1963). The Approach of Operational Research to Planning in India. Calcutta, India, Indian Statistical Institute. Indian Statistical Series No.18, June 29.

Mamdani, Mehmood (1976). Political Class Formation in Uganda. Heineman, London.

Maneepong, Chuthatip and Chung-Tong Wu (2004), "Comparative Borderland Developments in Thailand”, ASEAN Economic Bulletin Vol. 21, No. 2 (2004), pp. 135-66.

Manezhev, S.A. (1995). "Free Economic Zones and the Economic Transition in the Chinese People’s Republic and Russia”. Russian and East European Finance and Trade. March-April. Pp.76-87.

Morris, Sebastian (1997), . "Why Not Push for 9\% Growth”, Economic and Political Weekly, May 17-24, pp.1153-1165, 1997.

Morris, Sebastian (1997), "Why Not Push for 9\% Growth ? Economic and Political Weekly, April, 19971-24 May,1997.

Morris, Sebastian (2001a), “Towards a Conceptual and Analytical Framework”, chapter 2, in Morris, Sebastian et al (2001).

Basant, Rakesh and Sebastian Morris (2002), "Investment for Development: The Case of Seven Economies in Transition", May, Mimeo. A synthesis paper prepared for Consumer Unity and Trust Society (CUTS), Jaipur.

Morris, Sebastian (2004), "A Study of the Regional Determinants of Foreign Direct Investments in India, and the Case of Gujarat”, WP No. 2004/03/07, Indian Institute of Management Ahmedabad.

Morris, Sebastian (2005). "Understanding Export Led Growth and Late Industrialisation to Explain the Differences in the Post Reform Performance of India and China”, WP No. 2005/03/02, March. Indian Institute of Management Ahmedabad.

Morris, Sebastian; Rakesh Basant; Keshab Das, Kavil Ramachandran, Abraham Koshy (2001). Growth and Transformation of Small Firms in India. New Delhi, Oxford University Press.

Mukhopadhayay, Partha (2001). “Do De-nova SEZs Make Sense?”, Prepared by Dr. Partha Mukhoppadhayay for the Infrastructure Development Finance Company, Chennai. October.

Ndikumana, L. and T. Hall (c2000). Is Africa a Net Creditor? New Estimates of Capital Flight from Severly Indebted Sub-Sharan African Countries, 1970-1996. University of Massachusetts, Amherst, MA 01003.

Ozawa, Terutomo (1979), Multinationalism, Japanese Style: The Political Economy of Outward Dependency, Princeton, NJ: Princeton University Press

Page, John (1994), “The East Asian Miracle: An Introduction”, World Development, April 1994, v. 22, No. 4, pp. 615-25

Pandey, Ajay (2006), "Recent Policy Initiatives on SEZs in India: An Analytical Review", report submitted to the UK High Commission on SEZs. Indian Institute of Management Ahmedabad, mimeo

Park, Y. C. (1981). Export-Led Development: The Korean Experience 1960-78, International Labour Organization. in Lee, Eddy (ed) (1981).

Parthasarathy, Ravi "Financing Of Special Economic Zones”, Infrastructure Leasing \& Financial Services Limited April 30, 2004, mimeo as presentation, Vice Chairman \& Managing Director.

Pastor-Jr, M. (1990). Capital Flight from Latin America. World Development: Vol.18, No.1, pp.1-18. 
Petras, J. and H. Brill (1988). Latin America's Transnational Capitalists and the Debt: A Class-Analysis Perspective. Development and Change: Vol.19, No.2, April, pp.179-201.

Shivji, Issa (1976). Class Struggles in Tanzania. Monthly Review Press, New York.

Singh, Manmohan (1964), "India's Export Trends and the Prospects for Self-Sustained Growth”, Oxford, Clarendon Press.

Sung, Yu-Wing (1991), “The China - Hong Kong Connection: The Key to China's Open Door Policy”, Cambridge, Cambridge Univ. Press.

Tyler, W. G., E. I. F. D. M. Sales, et al. (1985). A View of Anti-Export Biases and Commercial Policy in Brazil, 1980-81. Journal of Developing Economies: Vol.18, pp.219-242.

Vaitsos, C. (1978). Regional Economic Cooperation (Integration) among Developing Countries: A Survey. World Development : pp. 719-769.

Victor F. S. Sit and Chun Yang. "Foreign-investment-induced Exo-urbanisation in the Pearl River Delta, China”. Urban Studies, Vol. 34, No. 4, 647 \pm 677, 1997

Warr, Peter G. (c.1987). "Export Promotion via Industrial Enclaves: The Philippines Bataan Export Processing Zone”. The Journal of Development Studies. Copyright 2002, EBSCO Publishing.

Wei, Xie (2000). “Acquisition Of Technological Capability through Special Economic Zones (SEZs): The Case of Shenzhen SEZ”. Industry And Innovation. Volume 7, Number 2, 199-221, December 2000.

Wei, Yehua Dennis And Chi Kin Leung (2005). Development Zones, Foreign Investment, and Global City Formation In Shanghai. Growth And Change. Vol. 36 No. 1 (Winter 2005), Pp. 16-40[Data on zones and various SEZs in the city and around their industrial specialisation, the global firms that operate etc.]

World Bank (1984), “India: Non-Electrical Machinery Subsector,” Industry Department, The World Bank, Washington, D.C., New Delhi.

World Bank (1993), “The East Asian Miracle: Economic Growth and Public Policy”, Policy Research Report, Washington D.C.

Zhang, Jie and Gustav Kristensen (2001). "The paradox of unequal regional investment and equal regional economic growth in China”. Annals of Regional Science (2001) 35:637-655.

Zhou, Changhui; Andrew Delios And Jing Yu Yang (2001). Locational Determinants Of Japanese Foreign Direct Investment In China. Asia Pacific Journal Of Management. (forthcoming). mimeo. October 23.

Zhu, Jieming , (1994), “Changing Land Policy and its Impact on Local Growth: The Experience of the Shenzhen Special Economic Zone, China, in the 1980s”, Urban Studies, Vol. 31, No. 10, 1994 1611-1623. 
Table 1: Salient Features of Economic Strategies Attempting to Bring About the Economic Transformation

\begin{tabular}{|c|c|c|c|}
\hline $\begin{array}{l}\text { Aspect of growth } \\
\text { and development }\end{array}$ & Export Led Growth & Import Substitution & Laissez Faire \\
\hline $\begin{array}{l}\text { Overall } \\
\text { characterisation }\end{array}$ & $\begin{array}{l}\text { Simultaneous promotion of } \\
\text { exports and importables. } \\
\boldsymbol{P}_{X} / \boldsymbol{P}_{n t}, \boldsymbol{P}_{\boldsymbol{m}} / \boldsymbol{P}_{n t} \text { much greater } \\
\text { than otherwise trough Import- } \\
\text { Substitution and Export } \\
\text { Promotion being } \\
\text { simultaneously pursued. } \\
\boldsymbol{P}_{\boldsymbol{x}} / \boldsymbol{P}_{\boldsymbol{m}} \text { could well be at border } \\
\text { ratios deceiving most } \\
\text { economists (including WB) } \\
\text { into characterising ELG as } \\
\text { laissez-faire (or the movement } \\
\text { to laissez faire) . Trade ratio } \\
\text { rises much faster than world } \\
\text { average. }\end{array}$ & $\begin{array}{l}\text { "Classical" import } \\
\text { substitution of the Lisztian } \\
\text { variety. Import goods } \\
\text { production is encouraged. } \\
\text { Exports typically suffer. } \\
\text { Trade ratio typically falls } \\
\text { with this strategy. } \boldsymbol{P}_{m} / \boldsymbol{P}_{x}>\text { the } \\
\text { border prices, creating } \\
\text { positive incentives for IS and } \\
\text { negative for exports goods } \\
\text { production. Trade ratio in a } \\
\text { sense relative to the world } \\
\text { falls. }\end{array}$ & $\begin{array}{l}\boldsymbol{P}_{m} / \mathbf{P}_{x}=\text { border } \\
\text { ratio. Trade ratio } \\
\text { remains } \\
\text { unchanged moves } \\
\text { along with } \\
\text { international } \\
\text { developments }\end{array}$ \\
\hline Exchange rates & $\begin{array}{l}\text { The effective exchange rate } \\
\text { would be highly undervalued }\end{array}$ & $\begin{array}{l}\text { The effective exchange rate is } \\
\text { typically overvalued }\end{array}$ & $\begin{array}{l}\text { The effective } \\
\text { exchange rate is } \\
\text { usually at } \\
\text { "equilibrium". }\end{array}$ \\
\hline Tariffs & $\begin{array}{l}\text { Tariffs could be large but need } \\
\text { not be. Typical pattern is of } \\
\text { high tariffs for IS industries } \\
\text { which then are reduced as } \\
\text { they mature to become export } \\
\text { industries. With time no tariff } \\
\text { protection is required. }\end{array}$ & $\begin{array}{l}\text { Tariffs on protected IS } \\
\text { industries are large and } \\
\text { overall level of tariffs could } \\
\text { be high. Effective protection } \\
\text { could vary widely. }\end{array}$ & $\begin{array}{l}\text { Little or no tariff } \\
\text { protection }\end{array}$ \\
\hline $\begin{array}{l}\text { Comparative } \\
\text { advantage }\end{array}$ & $\begin{array}{l}\text { Builds on the unfoldment of } \\
\text { dynamic comparative } \\
\text { advantage. Yesterday's IS } \\
\text { industries become today's } \\
\text { export industries }\end{array}$ & $\begin{array}{l}\text { Creates new industries but } \\
\text { the syndrome of dependence } \\
\text { on protection is high. Exports } \\
\text { are usually limited to natural } \\
\text { resources and to products and } \\
\text { services of absolute } \\
\text { advantage }\end{array}$ & $\begin{array}{l}\text { Static comparative } \\
\text { advantage. }\end{array}$ \\
\hline Competitive factors & $\begin{array}{l}\text { ELG being based on exports } \\
\text { exposes its actors to the } \\
\text { discipline of the global market } \\
\text { to put enormous pressure to be } \\
\text { efficient and market } \\
\text { responsive. }\end{array}$ & $\begin{array}{l}\text { Protection is high so } \\
\text { competitive factors are } \\
\text { underdeveloped }\end{array}$ & $\begin{array}{l}\text { Only a slow } \\
\text { change in } \\
\text { competitive } \\
\text { factors is possible }\end{array}$ \\
\hline $\begin{array}{l}\text { Basis of } \\
\text { comparative } \\
\text { advantage }\end{array}$ & $\begin{array}{l}\text { Natural resource (for a short } \\
\text { period)- semiskilled and } \\
\text { otherwise under/un employed } \\
\text { labour - capital intensive } \\
\text { standardised goods - skilled } \\
\text { labour intensive goods - } \\
\text { differentiated goods in a } \\
\text { evolutionary fashion. }\end{array}$ & $\begin{array}{l}\text { Comparative advantage } \\
\text { artificially suppressed. Only } \\
\text { idiosyncratic revelation of } \\
\text { comparative advantage }\end{array}$ & $\begin{array}{l}\text { Comparative } \\
\text { advantage is non- } \\
\text { evolving and the } \\
\text { lack or slow } \\
\text { development of } \\
\text { competitive } \\
\text { factors prevents } \\
\text { the engagement of } \\
\text { possible idle } \\
\text { labour. }\end{array}$ \\
\hline
\end{tabular}




\begin{tabular}{|c|c|c|c|}
\hline Terms of trade & $\begin{array}{l}\text { Fall rapidly as these countries } \\
\text { penetrate the markets of the } \\
\text { advanced countries. This } \\
\text { happens for quite a while until } \\
\text { the stage of differentiated } \\
\text { goods in reached. Yet the } \\
\text { volume expansion is so large } \\
\text { that the country gains. } \\
\text { Destination countries also } \\
\text { gain enormously and so the } \\
\text { strategy is politically also } \\
\text { feasible. ELG countries are } \\
\text { able to suffer a terms of trade } \\
\text { decline since they are able to } \\
\text { use idle /under utilised labour. } \\
\text { Once DU is over the gross } \\
\text { labour productivity rises } \\
\text { (VA/L) rapidly enough to be } \\
\text { larger than the terms of trade } \\
\text { decline, so that there is all } \\
\text { round gain. }\end{array}$ & $\begin{array}{l}\text { May fall or rise - no } \\
\text { unambiguous trajectory is } \\
\text { expected. Driven by the } \\
\text { idiosyncratic composition of } \\
\text { the trade basket. But terms of } \\
\text { trade could be affected by the } \\
\text { relative price fall of labour } \\
\text { intensive and other } \\
\text { manufacaturers taking place } \\
\text { globally due to other ELG } \\
\text { countries. }\end{array}$ & $\begin{array}{l}\text { No unambiguous } \\
\text { trajectory is } \\
\text { expected. But } \\
\text { subject to global } \\
\text { trade of } \\
\text { manufacturing } \\
\text { goods prices } \\
\text { falling as other } \\
\text { countries pursue } \\
\text { ELG. }\end{array}$ \\
\hline $\begin{array}{l}\text { Capital formation } \\
\text { rate }\end{array}$ & $\begin{array}{l}\text { Generally high - above } 30 \% \\
\text { of GDP on a sustainable basis }\end{array}$ & $\begin{array}{l}\text { Moderate with a range from } \\
20 \% \text { to } 30 \% \text { (India) }\end{array}$ & $\begin{array}{l}\text { Low typically } \\
\text { below } 20 \% \text { of } \\
\text { GDP unless there } \\
\text { are special factors. }\end{array}$ \\
\hline $\begin{array}{l}\text { Equality of income } \\
\text { distribution }\end{array}$ & $\begin{array}{l}\text { Growth is equality (especially } \\
\text { when measured in terms of } \\
\text { consumption) promoting since } \\
\text { much of the additional value } \\
\text { added is either invested or } \\
\text { earned by new workers. This } \\
\text { is more so in the early phase } \\
\text { when disguised } \\
\text { unemployment is being } \\
\text { overcome. In the latter phase } \\
\text { of differentiated goods } \\
\text { industries there could be some } \\
\text { divergence }\end{array}$ & $\begin{array}{l}\text { Growth can be highly } \\
\text { iniquitous since large rents } \\
\text { and spending out of the rents } \\
\text { arise in IS and idiosyncratic } \\
\text { industries of natural } \\
\text { advantage. }\end{array}$ & $\begin{array}{l}\text { Since structural } \\
\text { change is hardly } \\
\text { there, the changes } \\
\text { in income } \\
\text { distribution are } \\
\text { likely to be } \\
\text { modest. When } \\
\text { such small } \\
\text { economies have } \\
\text { tended to } \\
\text { specialise in } \\
\text { services, some } \\
\text { worsening of the } \\
\text { income } \\
\text { distribution is } \\
\text { likely. }\end{array}$ \\
\hline $\begin{array}{l}\text { Role of the state in } \\
\text { investments }\end{array}$ & $\begin{array}{l}\text { Have varied with moderate to } \\
\text { very high }\end{array}$ & Have been moderate to high & Low \\
\hline $\begin{array}{l}\text { State direction and } \\
\text { control over } \\
\text { resource allocation }\end{array}$ & $\begin{array}{l}\text { Generally high especially in } \\
\text { the early phases }\end{array}$ & High to moderate & Low \\
\hline $\begin{array}{l}\text { Rates of growth } \\
\text { possible to achieve }\end{array}$ & $\begin{array}{l}\text { Very high in the range of } 7- \\
12 \% \text { per annum on a sustained } \\
\text { basis for as long as } 15-20 \\
\text { years to take the economy } \\
\text { through transition }\end{array}$ & $\begin{array}{l}\text { Moderate growth rates over } \\
\text { the longer period typically } \\
\text { less than } 5 \% \text { on an average at } \\
\text { best (India in recent times) } \\
\text { and sustainability is not } \\
\text { guaranteed. No late } 20^{\text {th }} \\
\text { century successes. High } \\
\text { variability in growth rates } \\
\text { possible. }\end{array}$ & $\begin{array}{l}\text { Low to moderate } \\
\text { growth rates with } \\
\text { high variability in } \\
\text { rates. Unless } \\
\text { special conditions } \\
\text { - access to a } \\
\text { continental market } \\
\text { or customs union } \\
\text { is limiting }\end{array}$ \\
\hline
\end{tabular}




\begin{tabular}{|c|c|c|c|}
\hline $\begin{array}{l}\text { Diversification of } \\
\text { the economy that } \\
\text { results }\end{array}$ & $\begin{array}{l}\text { Very high level of } \\
\text { diversification possible that is } \\
\text { also efficient }\end{array}$ & $\begin{array}{l}\text { Very high level of } \\
\text { diversification particularly } \\
\text { when there is the added push } \\
\text { to heavy and capital goods } \\
\text { sectors (India 1955-65; and } \\
\text { China 1965-70) ; but many } \\
\text { sectors are underscaled and } \\
\text { inefficient. }\end{array}$ & $\begin{array}{l}\text { Not much change } \\
\text { in the structure of } \\
\text { the economy. A } \\
\text { slow change could } \\
\text { be observed. }\end{array}$ \\
\hline $\begin{array}{l}\text { Absorption of } \\
\text { disguised } \\
\text { unemployed }\end{array}$ & $\begin{array}{l}\text { Can happen in a short period } \\
\text { of } 10 \text { years. }\end{array}$ & $\begin{array}{l}\text { Is usually left incomplete } \\
\text { before the transition to laissez } \\
\text { faire takes place }\end{array}$ & $\begin{array}{l}\text { DU can only } \\
\text { continue; unless } \\
\text { the economy on } \\
\text { specific } \\
\text { favourable factors. }\end{array}$ \\
\hline Factor productivity & $\begin{array}{l}\text { The factor productivity is } \\
\text { likely to be large given the } \\
\text { quick unfoldment of learning } \\
\text { curves, scale and scope } \\
\text { factors. But as share of the } \\
\text { total output growth the factor } \\
\text { productivity is likely to be } \\
\text { small, since much of the } \\
\text { growth is expected from } \\
\text { absorption of labour as the } \\
\text { capital stock in the economy } \\
\text { increases. The period of early } \\
\text { growth with constant real } \\
\text { wages, high rates of } \\
\text { employment growth, constant } \\
\text { (or marginally falling) capital } \\
\text { intensity is most functional to } \\
\text { the transformation process. }\end{array}$ & $\begin{array}{l}\text { Demand side limitations and } \\
\text { small market sizes and the } \\
\text { attendant dependence on } \\
\text { tariff protection (especially } \\
\text { to start with) limit the total } \\
\text { factor productivity to small } \\
\text { levels. Even then the share of } \\
\text { TFP could be similar or } \\
\text { sometimes even better } \\
\text { especially if the enclaved } \\
\text { sector does not absorb labour. } \\
\text { This is dysfunctional. In IS } \\
\text { economies that were also } \\
\text { inward looking (India } 1955 \text { to } \\
\text { 1992, and China over the } \\
\text { GLF and CR periods) many } \\
\text { industries would have also } \\
\text { shown negative value } \\
\text { addition if the inputs had } \\
\text { been correctly accounted for. }\end{array}$ & $\begin{array}{l}\text { Factor } \\
\text { productivity } \\
\text { changes are likely } \\
\text { to dominate while } \\
\text { there is little } \\
\text { impact on the } \\
\text { absorption of idle } \\
\text { labour unless there } \\
\text { are special } \\
\text { favourable factors. }\end{array}$ \\
\hline $\begin{array}{l}\text { Role of foreign } \\
\text { savings }\end{array}$ & $\begin{array}{l}\text { Conceptually this strategy } \\
\text { does not require any foreign } \\
\text { savings. But in the initial } \\
\text { period some of the ELG } \\
\text { economies (Taiwan, South } \\
\text { Korea) do show major } \\
\text { dependence on foreign } \\
\text { savings which is overcome } \\
\text { over an eight year period. } \\
\text { Typically high rates of } \\
\text { investment are matched by } \\
\text { high rates of domestic savings } \\
\text { and some like China have } \\
\text { even been net capital } \\
\text { exporters as they undergo } \\
\text { their transformation at rapid } \\
\text { rates. }\end{array}$ & $\begin{array}{l}\text { Foreign savings become } \\
\text { necessary since the capital } \\
\text { intensity can be expected to } \\
\text { rise as IS is pushed deep } \\
\text { down. Even if potentially the } \\
\text { domestic savings are large } \\
\text { they may not be realisable as } \\
\text { overvaluation of the } \\
\text { exchange rates usually result } \\
\text { in significant deficits in the } \\
\text { current account. "Excess" } \\
\text { domestic savings are then } \\
\text { "exported” out through } \\
\text { various ways including } \\
\text { capital flight and capital } \\
\text { exports (especially when } \\
\text { these economies are also } \\
\text { open on the capital account - } \\
\text { Many of the Latin American } \\
\text { economies for example). }\end{array}$ & $\begin{array}{l}\text { Foreign savings } \\
\text { are limited by the } \\
\text { amount of } \\
\text { sustainable private } \\
\text { capital inflow } \\
\text { which on a } \\
\text { sustained basis is } \\
\text { not large since } \\
\text { there is little } \\
\text { structural change } \\
\text { taking place in the } \\
\text { economy. For the } \\
\text { more developed } \\
\text { LF economies } \\
\text { foreign savings are } \\
\text { negative i.e. there } \\
\text { is significant } \\
\text { export of capital. }\end{array}$ \\
\hline
\end{tabular}




\begin{tabular}{|c|c|c|c|}
\hline $\begin{array}{l}\text { Non-resource } \\
\text { seeking FDI } \\
\text { quantum }\end{array}$ & $\begin{array}{l}\text { Large inflows possible which } \\
\text { are nevertheless small in } \\
\text { relation to domestic } \\
\text { investments. Wide variation in } \\
\text { the openness to FDI, yet FDI } \\
\text { (city states excepted) have not } \\
\text { been large relative to capital } \\
\text { formation }\end{array}$ & $\begin{array}{l}\text { Moderate inflows possible } \\
\text { which can be large in relation } \\
\text { to domestic investments. FDI } \\
\text { regimes have ranged form the } \\
\text { very liberal (Latin America) } \\
\text { to the most ill-liberal (India } \\
\text { before 1991) }\end{array}$ & $\begin{array}{l}\text { Typically liberal } \\
\text { to FDI. FDI } \\
\text { dominance is } \\
\text { large. }\end{array}$ \\
\hline $\begin{array}{l}\text { Nature of Non - } \\
\text { Resource seeking } \\
\text { FDI }\end{array}$ & $\begin{array}{l}\text { Much of it is directed to } \\
\text { production for the export } \\
\text { market }\end{array}$ & $\begin{array}{l}\text { There very little FDI directed } \\
\text { at the export market nearly all } \\
\text { of it is directed at a protected } \\
\text { (or shielded) home market. } \\
\text { Non-tradables would attract } \\
\text { FDI. }\end{array}$ & $\begin{array}{l}\text { FDI is in many } \\
\text { sectors including } \\
\text { what would be } \\
\text { non-tradables. }\end{array}$ \\
\hline $\begin{array}{l}\text { Role of Non-Equity } \\
\text { forms of } \\
\text { transnational } \\
\text { involvement }\end{array}$ & $\begin{array}{l}\text { Of much importance in the } \\
\text { exports of mfg, through } \\
\text { arrangements such as OEM, } \\
\text { and international } \\
\text { subcontracting. Can be very } \\
\text { high especially in those } \\
\text { economies where FDI is } \\
\text { restricted (South Korea, } \\
\text { Taiwan, Japan and China). } \\
\text { Buying by retail and } \\
\text { wholesale chain stores also of } \\
\text { importance. So also the role of } \\
\text { trading houses. }\end{array}$ & $\begin{array}{l}\text { Of little importance since } \\
\text { much of the transnational } \\
\text { corporation interest is in } \\
\text { serving the domestic market. } \\
\text { Trading houses have some } \\
\text { role especially in the little } \\
\text { exports and in the imports of } \\
\text { machinery and materials. }\end{array}$ & $\begin{array}{l}\text { Little scope for } \\
\text { non-arms length } \\
\text { arrangements. } \\
\text { Buying by large } \\
\text { retail chain stores } \\
\text { is the only non- } \\
\text { equity form. } \\
\text { Limited role for } \\
\text { trading houses. }\end{array}$ \\
\hline Role of FDI & $\begin{array}{l}\text { The principal contribution of } \\
\text { FDI is in terms of the positive } \\
\text { externalities -learning by } \\
\text { imitation, spillovers of } \\
\text { technology and work } \\
\text { practices, access to marketing } \\
\text { and technology etc. The role } \\
\text { of FDI as a contributor to } \\
\text { savings is less important } \\
\text { especially in the latter stages. } \\
\text { Even China is not an } \\
\text { exception if one recognises } \\
\text { that 80\% or more of FDI into } \\
\text { China is mere round tripping } \\
\text { or arising out of the cross- } \\
\text { county investment links of } \\
\text { the Chinese bourgeoisie. FDI } \\
\text { is therefore almost completely } \\
\text { complimentary to domestic } \\
\text { capital }\end{array}$ & $\begin{array}{l}\text { FDI is often displaces } \\
\text { domestic savings and } \\
\text { investments since the } \\
\text { macroeconomic policies } \\
\text { result in asymmetry between } \\
\text { the cost of capital in the } \\
\text { domestic economy which is } \\
\text { higher than in the cost of } \\
\text { capital in source countries. } \\
\text { When so, FDI can be } \\
\text { dysfunctional and result in } \\
\text { take over of domestic assets. } \\
\text { The spillover effects are still } \\
\text { significant but much smaller } \\
\text { than in the case of ELG. FDI } \\
\text { tends to displace domestic } \\
\text { capital and can when not } \\
\text { restricted lead to 'de- } \\
\text { nationalisation” of domestic } \\
\text { business; i.e. substitutes }\end{array}$ & $\begin{array}{l}\text { Spillovers are } \\
\text { small and FDI's } \\
\text { role is dictated by } \\
\text { industrial } \\
\text { economic } \\
\text { considerations in a } \\
\text { laissez faire } \\
\text { economy. The is } \\
\text { neither } \\
\text { substitutability nor } \\
\text { complimentarity. }\end{array}$ \\
\hline
\end{tabular}

WB: See Text. $\mathrm{P}_{\mathrm{n}}, \mathrm{P}_{\mathrm{x}}, \mathrm{P}_{\mathrm{m}}$, Price of non-tradable, exports and imports in that order. 
Table 2 Salient Features of Special Economic Zones Under Various Transformation Strategies

\begin{tabular}{|c|c|c|c|}
\hline $\begin{array}{l}\text { Aspect of } \\
\text { Special/ Free } \\
\text { Economic Zone }\end{array}$ & $\begin{array}{l}\text { Export Led Growth } \\
\text { Economies }\end{array}$ & Import Substitution & Laissez Faire \\
\hline $\begin{array}{l}\text { Share of zones in } \\
\text { overall investment }\end{array}$ & $\begin{array}{l}\text { Can vary widely depending } \\
\text { upon the strategy pursued. } \\
\text { But in the early stages the } \\
\text { share of special zones can be } \\
\text { significant. Thus SK and } \\
\text { Taiwan had small significant } \\
\text { shares but China had vary } \\
\text { large share of investment (c. } \\
5 \% \text { or more) going into the } \\
\text { zones. The principal } \\
\text { determinants besides the } \\
\text { fiscal and the infrastructural } \\
\text { is the large bias in favour of } \\
\text { exports. }\end{array}$ & $\begin{array}{l}\text { Very little almost negligible } \\
\text { shares of investment go into } \\
\text { special zones, since their } \\
\text { logic when the overall policy } \\
\text { is biased against exports is in } \\
\text { opposition. (India, } \\
\text { Bangladesh, Nepal, much of } \\
\text { Latin America before the } \\
\text { take off the regional trade } \\
\text { agreements). While the } \\
\text { fiscal and the infrastructural } \\
\text { factors when favourable can } \\
\text { attract investments, these } \\
\text { have to overcome the large } \\
\text { bias against tradable goods } \\
\text { (especially exports goods) } \\
\text { production }\end{array}$ & $\begin{array}{l}\text { Zones when the only } \\
\text { option can have small } \\
\text { shares of investment. } \\
\text { Cheap infrastructure } \\
\text { or favourable location } \\
\text { can drive investments } \\
\text { into the area. The } \\
\text { determinants are the } \\
\text { fiscal and } \\
\text { infrastructural factors. }\end{array}$ \\
\hline $\begin{array}{l}\text { Share of } \\
\text { employment in } \\
\text { zones }\end{array}$ & $\begin{array}{l}\text { Is usually large (and much } \\
\text { larger than the share of } \\
\text { investment) in the early days } \\
\text { when the functionality of } \\
\text { ELG is to absorb the } \\
\text { unemployed/ underemployed } \\
\text { labour. In later stages as the } \\
\text { economy as such modernises } \\
\text { and the IS industries now } \\
\text { become export industries the } \\
\text { role of zones comes down. } \\
\text { In China the role of zones } \\
\text { has continued to be large } \\
\text { since zones got defined to } \\
\text { include cities and the } \\
\text { surrounding areas in as } \\
\text { ascendant manner as the rest } \\
\text { of the economy developed } \\
\text { and (re-)modernised under } \\
\text { ELG. }\end{array}$ & $\begin{array}{l}\text { Very small share in } \\
\text { employment usually. (Much } \\
\text { of South Asia). In those } \\
\text { economies with favourable } \\
\text { trade arrangements like } \\
\text { NAFTA, or regional trade } \\
\text { arrangements, processing } \\
\text { industries despite the bias } \\
\text { against exports can take root } \\
\text { to give significant } \\
\text { employment of unskilled and } \\
\text { semiskilled labour. } \\
\text { ' 'Maquiladora' industries in } \\
\text { Mexico for example\}. But as } \\
\text { the bias can increase due to } \\
\text { uncorrected overvaluation of } \\
\text { the exchange rates these are } \\
\text { not steady employment. }\end{array}$ & $\begin{array}{l}\text { Could be significant } \\
\text { when zones are } \\
\text { defined to be large. } \\
\text { Otherwise small share. }\end{array}$ \\
\hline $\begin{array}{l}\text { Role of FDI in } \\
\text { zones }\end{array}$ & $\begin{array}{l}\text { FDI can be the initial spurts } \\
\text { for take off the zones, but is } \\
\text { quickly followed by } \\
\text { domestic investments. Since } \\
\text { much of the FDI is labour } \\
\text { seeking and since are } \\
\text { promoted inter alia to absorb } \\
\text { idle labour the role of FDI in } \\
\text { zones tends to be larger than } \\
\text { the role of FDI over the rest } \\
\text { of the economy. This may be } \\
\text { enhanced by policies that bar } \\
\text { FDI outside the zones } \\
\text { (China until the early } \\
\text { nineties, Korea in the first } \\
\text { phase of ELG). \{the } \\
\text { extremely large of 'FDI' in } \\
\text { China into the zones is } \\
\text { additionally on account of }\end{array}$ & $\begin{array}{l}\text { Whatever little FDI that is } \\
\text { semi-skilled and skilled } \\
\text { labour seeking is confined } \\
\text { almost exclusively to the } \\
\text { zones since investments here } \\
\text { have the least bias against } \\
\text { exports. Much of the FDI } \\
\text { being internal market } \\
\text { oriented has otherwise little } \\
\text { role in zones especially those } \\
\text { that are exporting. }\end{array}$ & $\begin{array}{l}\text { No expected } \\
\text { difference between the } \\
\text { zones and the rest of } \\
\text { the economy other } \\
\text { than that } \\
\text { infrastructurally and } \\
\text { fiscally determined. }\end{array}$ \\
\hline
\end{tabular}




\begin{tabular}{|c|c|c|c|}
\hline & $\begin{array}{l}\text { about } 80 \% \text { of FDI being } \\
\text { misclassified as such when it } \\
\text { is in reality domestic } \\
\text { surpluses exported to be } \\
\text { reinvested through HK, and } \\
\text { Taiwan front firms }\end{array}$ & & \\
\hline $\begin{array}{l}\text { Growth rate of } \\
\text { output of zones. }\end{array}$ & $\begin{array}{l}\text { Can be very large matching } \\
\text { or even exceeding the } \\
\text { export growth rates } \\
\text { especially in the early phase } \\
\text { when the exports arise } \\
\text { largely from the zones. As } \\
\text { the rest of the economy } \\
\text { catches up in exports, the } \\
\text { overall growth rates of zones } \\
\text { slow down to more normal } \\
\text { levels (closer to the GDP } \\
\text { growth rates). } \text { The case of } \\
\text { China where the zonal } \\
\text { growth rates have continued } \\
\text { to be large even larger than } \\
\text { the export growth rates is } \\
\text { because of the continuous } \\
\text { administrative reworking of } \\
\text { domestic areas as new zones. } \\
\text { Particular zones though } \\
\text { show the expected pattern of } \\
\text { very high growth followed } \\
\text { by moderate growth\} }\end{array}$ & $\begin{array}{l}\text { Very small beyond an initial } \\
\text { growth. Few zones are even } \\
\text { occupied to capacity. Overall } \\
\text { growth rate tends to be } \\
\text { slower than GDP of all } \\
\text { export /special zones put } \\
\text { together. This is only to be } \\
\text { expected since policies are } \\
\text { biased against exports. Only } \\
\text { in periods when world trade } \\
\text { as whole grows much faster } \\
\text { than world GDP can the } \\
\text { zones in these areas be } \\
\text { expected to grow somewhat } \\
\text { faster than GDP. }\end{array}$ & $\begin{array}{l}\text { Zones of little } \\
\text { functional } \\
\text { significance. Being } \\
\text { largely an } \\
\text { administrative } \\
\text { category the zones } \\
\text { would grow at } \\
\text { idiosyncratic rates } \\
\text { deepening upon the } \\
\text { structure of industries } \\
\text { in the zone. }\end{array}$ \\
\hline $\begin{array}{l}\text { Growth spill - } \\
\text { overs from zones }\end{array}$ & $\begin{array}{l}\text { Very large, and countries } \\
\text { have different strategies to } \\
\text { capture the same. For S } \\
\text { Korea, Taiwan and Thailand, } \\
\text { the spillovers were allowed } \\
\text { to be captured by the rest of } \\
\text { the economy as such, to } \\
\text { makes the zones as such } \\
\text { irrelevant with the passage } \\
\text { of time. In the case of China, } \\
\text { area extension and new } \\
\text { zones (including declared } \\
\text { rather than constructed } \\
\text { zones) with links to the older } \\
\text { zones and to urban } \\
\text { agglomerations have } \\
\text { allowed the capture of the } \\
\text { positive spillovers in a } \\
\text { directed spatial pattern that } \\
\text { also had locational } \\
\text { functionality. This was } \\
\text { desirable given the large size } \\
\text { of the Chinese economy } \\
\text { (both in population and } \\
\text { area). }\end{array}$ & $\begin{array}{l}\text { Very little direct spillovers } \\
\text { from the zones. Some } \\
\text { indirect (distantly } \\
\text { attributable) spillovers from } \\
\text { the absolute advantage } \\
\text { industries in the zones } \\
\text { possible (as in the case of } \\
\text { software from the SEEPZ in } \\
\text { India). }\end{array}$ & $\begin{array}{l}\text { Since there are no } \\
\text { externalities expected } \\
\text { anyway from } \\
\text { economic activities in } \\
\text { general, the little from } \\
\text { special zones would } \\
\text { not be significant. }\end{array}$ \\
\hline $\begin{array}{l}\text { Instrumentalities } \\
\text { of spillover }\end{array}$ & $\begin{array}{l}\text { Through the unfoldment of } \\
\text { dynamic comparative } \\
\text { advantage. As export } \\
\text { industries create demands } \\
\text { for IS industries these are } \\
\text { forced to become }\end{array}$ & $\begin{array}{l}\text { Very weak spillover process. } \\
\text { No sustainable dynamic } \\
\text { process exits. When there are } \\
\text { special trade and especially } \\
\text { deeper integration links [East } \\
\text { Europe reintegrating back }\end{array}$ & $\begin{array}{l}\text { None other than } \\
\text { through spending } \\
\text { effects. }\end{array}$ \\
\hline
\end{tabular}




\begin{tabular}{|c|c|c|c|}
\hline & $\begin{array}{l}\text { competitive as they now } \\
\text { serve global markets. The } \\
\text { growth impetus into the rest } \\
\text { of the economy or into new } \\
\text { special zones or into their } \\
\text { extension is based on } \\
\text { demand and so is } \\
\text { autonomous and nor } \\
\text { requiring close direction. } \\
\text { The sustainability of the } \\
\text { spillovers is also guaranteed. } \\
\text { The nature of spillovers } \\
\text { change with time. Initially it } \\
\text { is in absorbing labour and in } \\
\text { the spending effects of the } \\
\text { labour's income and in the } \\
\text { vast surpluses which } \\
\text { potentially raise the } \\
\text { investment rates. Next it is } \\
\text { in creating demands for now } \\
\text { IS and to become export } \\
\text { industries. Other spill-overs } \\
\text { have been in terms of } \\
\text { product quality, delivery } \\
\text { schedules, managerial } \\
\text { processes, and learning }\end{array}$ & $\begin{array}{l}\text { with Western Europe] the } \\
\text { spillovers can be as very } \\
\text { large and similar to those of } \\
\text { ELG, except that no distinct } \\
\text { phases need be observed. If } \\
\text { the integrating country is } \\
\text { also following ELG then the } \\
\text { spillovers and the growth } \\
\text { effects can be stupendously } \\
\text { large [China vis-à-vis Hong } \\
\text { Kong and Taiwan in the } \\
\text { early phase of zone based } \\
\text { exports and development]. }\end{array}$ & \\
\hline $\begin{array}{l}\text { Efficacy of fiscal } \\
\text { incentives in } \\
\text { zones }\end{array}$ & $\begin{array}{l}\text { Can be very high in the early } \\
\text { phase when the fiscal } \\
\text { concessions in the zones are } \\
\text { an important way to direct } \\
\text { the support to export } \\
\text { activities. But later the more } \\
\text { important factor is the } \\
\text { "effective relative } \\
\text { undervaluation of the } \\
\text { exchange rates" that works } \\
\text { to keep the rate of increase } \\
\text { in exports up. As such there } \\
\text { is no continued dependence } \\
\text { on the fiscal incentives }\end{array}$ & $\begin{array}{l}\text { Efficacy can vary but even if } \\
\text { high declines since the } \\
\text { "incentives" in the zone may } \\
\text { merely go to partly } \\
\text { overcome and neutralise the } \\
\text { bias against exports and } \\
\text { rarely to provide a positive } \\
\text { thrust to exports in a } \\
\text { sustained way. Dependence } \\
\text { on fiscal incentives in an } \\
\text { increasing way is usual with } \\
\text { the continuation of IS. When } \\
\text { IS changes towards LF the } \\
\text { dependence can come down, } \\
\text { but so would the continual } \\
\text { production of new export } \\
\text { industries that takes place in } \\
\text { ELG. }\end{array}$ & $\begin{array}{l}\text { Scope and hence } \\
\text { efficacy of the fiscal is } \\
\text { limited. No } \\
\text { dependence on fiscal } \\
\text { incentives but then } \\
\text { there is no process of } \\
\text { unfoldment of } \\
\text { dynamic comparative } \\
\text { advantage. }\end{array}$ \\
\hline $\begin{array}{l}\text { Dependence on } \\
\text { access to port and } \\
\text { external links }\end{array}$ & $\begin{array}{l}\text { Crucial for export based } \\
\text { zones which would be } \\
\text { dominant. At mature states } \\
\text { the continuation of the zonal } \\
\text { approach (China since 1997) } \\
\text { would mean that some zones } \\
\text { in high-tech need could be in } \\
\text { the interior and have more } \\
\text { normal links with the } \\
\text { external world. As the } \\
\text { volume expands greatly the } \\
\text { cost of transportation falls } \\
\text { since the scale and scope } \\
\text { factors are large in shipping. }\end{array}$ & $\begin{array}{l}\text { Necessary since the zones } \\
\text { are explicitly promoted as } \\
\text { export zones. But given the } \\
\text { limited volumes the export } \\
\text { reach the cost of transport } \\
\text { does not decline due to scale } \\
\text { factors in shipping. }\end{array}$ & $\begin{array}{l}\text { Transport factors are } \\
\text { usually good to start } \\
\text { with. When not on } \\
\text { even otherwise the } \\
\text { costs do not fall. }\end{array}$ \\
\hline $\begin{array}{l}\text { Role and } \\
\text { significance of }\end{array}$ & $\begin{array}{l}\text { Initially this is not } \\
\text { significant, but as the }\end{array}$ & $\begin{array}{l}\text { Rarely would the } \\
\text { agglomeration economies }\end{array}$ & $\begin{array}{l}\text { Agglomeration } \\
\text { economies beyond the }\end{array}$ \\
\hline
\end{tabular}




\begin{tabular}{|c|c|c|c|}
\hline $\begin{array}{l}\text { agglomeration } \\
\text { economies within } \\
\text { the zone }\end{array}$ & $\begin{array}{l}\text { activity level becomes very } \\
\text { large the agglomeration } \\
\text { economies emerge too } \\
\text { dominate other factors } \\
\text { especially the fiscal and } \\
\text { concessional. The } \\
\text { agglomeration factors are } \\
\text { initially horizontal but with } \\
\text { the unfoldment of } \\
\text { comparative advantage they } \\
\text { could span the vertical too as } \\
\text { the same zone is expanded } \\
\text { and chosen for the new } \\
\text { industries (Shenzen in } \\
\text { China). }\end{array}$ & $\begin{array}{l}\text { emerge strongly enough to } \\
\text { dominate over the fiscal and } \\
\text { state provided. }\end{array}$ & $\begin{array}{l}\text { horizontal would not } \\
\text { emerge as such since } \\
\text { the development is } \\
\text { based on static } \\
\text { comparative } \\
\text { advantage. }\end{array}$ \\
\hline Infrastructure & $\begin{array}{l}\text { There is a need for } \\
\text { infrastructure that is updated } \\
\text { continually. Infrastructure } \\
\text { cost per unit of exports or } \\
\text { value added can only decline }\end{array}$ & $\begin{array}{l}\text { Initially provided } \\
\text { infrastructure is often less } \\
\text { than fully utilised, and the } \\
\text { cost per unit can be high and } \\
\text { non-declining }\end{array}$ & $\begin{array}{l}\text { In laissez faire the } \\
\text { zones being little more } \\
\text { than designated areas } \\
\text { for activities, the costs } \\
\text { and need for } \\
\text { infrastructure need not } \\
\text { go wrong. }\end{array}$ \\
\hline $\begin{array}{l}\text { Social returns to } \\
\text { investments in } \\
\text { zones }\end{array}$ & $\begin{array}{l}\text { Very high especially of the } \\
\text { proving initial zones }\end{array}$ & Modest & $\begin{array}{l}\text { Low and sometimes } \\
\text { the benefits may not } \\
\text { even cover the cost of } \\
\text { infrastructure } \\
\text { especially if provided } \\
\text { in new (remote) areas. } \\
\text { Eg. Bataan in } \\
\text { Philippines. }\end{array}$ \\
\hline
\end{tabular}

